\title{
Role of tectonic burial and temperature on the inversion of inherited extensional basins during collision
}

\author{
MANFRED LAFOSSE*, ALEXANDRE BOUTOUX, NICOLAS BELLAHSEN \\ \& LAETITIA LE POURHIET \\ Sorbonne Universités, UPMC Univ Paris 06, CNRS, Institut des Sciences de la Terre de Paris (iSTeP), 4 Place Jussieu \\ 75005 Paris, France
}

(Received 6 November 2015; accepted 10 May 2016; first published online 28 June 2016)

\begin{abstract}
The style of inversion of inherited extensional basins in the Western Alps is investigated through thermo-mechanical modelling. Two-dimensional models consist of a half-graben embedded in a relatively strong crust (basement) and filled with weak syn-rift sediments (cover). We investigate the relative influence of the internal friction $(\mu)$ of the basin-bounding normal fault, tectonic burial (h) under an overlying nappe and the geothermal gradient. We use a viscoplastic model with symmetrical shortening. The inherited normal fault is implemented as a curved thin body with a variable friction coefficient $(\mu)$ ranging from 0.1 to 0.6 . The style of basin inversion is controlled at shallow depth by the internal friction coefficient, whose influence decreases with the increase of both burial depth and geothermal gradient. With increasing burial and/or geothermal gradient, fault reactivation is inhibited and distributed deformation in the basement induces the vertical extrusion of the cover. The basin inversion is accompanied by distributed deformation in the cover and by the shearing of the basin and basement interface. The results are consistent with the style of inversion of inherited half-grabens in the external Western Alps, where no significant fault reactivation occurred owing to tectonic burial underneath the Alpine internal units during the early Alpine collision.
\end{abstract}

Keywords: External Crystalline Massifs, thermo-mechanical modelling, Western Alps, collision, basin inversion.

\section{Introduction}

Restoration of external units in worldwide orogens shows that, most of the time, continental collision involves a previously stretched lithosphere whose margin contains extensional basins inherited from pre-orogenic rifting (e.g. Jackson, 1980; Lemoine et al. 1989; Beaumont et al. 2000; Marshak, Karlstrom \& Timmons, 2000; Lacombe \& Mouthereau, 2002; Butler, Tavarnelli \& Grasso, 2006; Bellahsen et al. 2012). In a thick-skinned deformation style setting (e.g. Lacombe \& Bellahsen, 2016, this issue), basement shortening during the collision is indeed usually characterized by the reactivation of well-oriented inherited extensional structures (e.g. inherited pre-orogenic normal faults; Jackson, 1980). It is noteworthy that such a setting occurs within previously rifted lithosphere, presenting a thermal age (i.e. duration between stretching and shortening, e.g. Burov \& Diament, 1995) lower than $1 \mathrm{Ga}$ (Mouthereau, Watts \& Burov, 2013).

Beyond the inherited thermal state of the lithosphere, Bonini, Sani \& Antonielli (2012) synthesized the analogue modelling literature to define three main factors governing the reactivation of an inherited normal fault: the steepness of the fault, its angle compared to the direction of compression and the fault frictional resistance. Depending on the variation of those three para-

*Author for correspondence: manfred.lafosse@upmc.fr meters, several types of reactivation can be defined: the development of low-angle thrusts, the propagation in the cover of a normal fault reactivated as a reverse fault and the development of a basement shortcut (Bonini, Sani \& Antonielli, 2012 and references therein). The style of inversion of inherited extensional basins was also investigated using numerical modelling (e.g. Buiter \& Pfiffner, 2003; Buiter, Pfiffner \& Beaumont, 2009), which shows that post-rift sediment thickness, the friction coefficient of faults, basin fill thermal conductivity and crustal geometry are important parameters. Moreover, they highlighted that localization of compressional deformation in the basin during crustal shortening is due to the rheological contrast between the weak basin and strong underlying basement. This contrast is often considered high at shallow depth, i.e. in the upper part of the crust. What would the style of basin inversion be in the case of a low rheological contrast, which can result, in particular, from significant burial and associated heating?

The External Crystalline Massifs (ECM, Fig. 1), located in the hinterland of the Western Alps external zone, were shortened with a thick-skinned style and inherited extensional basins were inverted during Oligo-Miocene collision (e.g. Burkhard \& Sommaruga, 1998; Butler, Tavarnelli \& Grasso, 2006). There, inherited normal faults are either interpreted as reactivated (Gillcrist et al. 1987; Burkhard, 1988; Burkhard \& Sommaruga, 1998; Bonnet et al. 2007) or not (Bellahsen et al. 2012; 


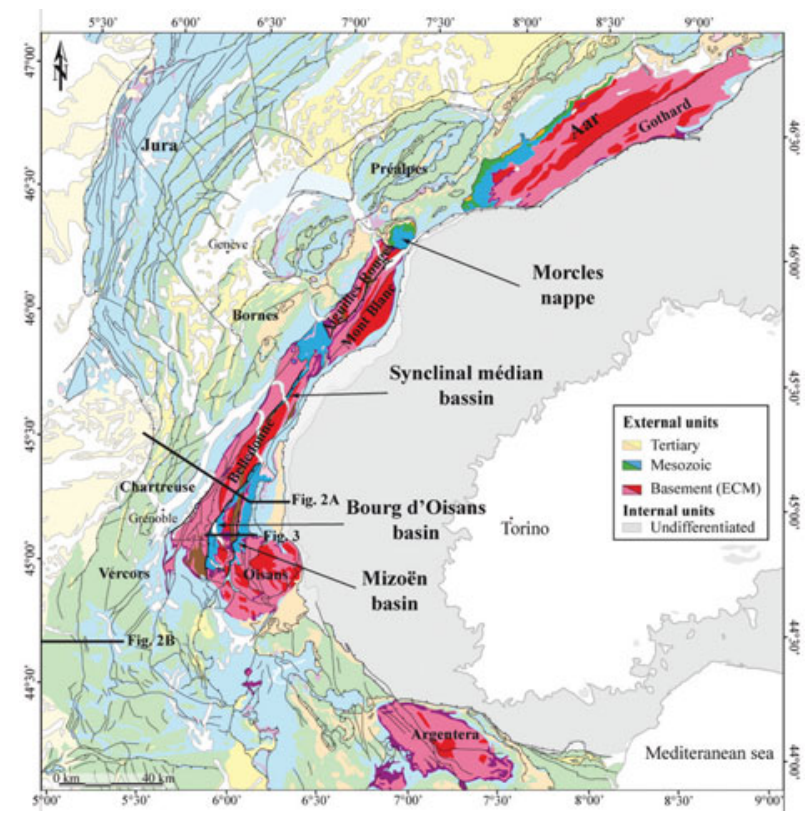

Figure 1. (Colour online) Geological map of the Western Alps with location of the External Crystalline Massifs and structures cited in this contribution.

Boutoux et al. 2014a). In the latter case, the shortening is accommodated by vertical extrusion of the basin and distributed deformation in the basement. In the ECM, tectonic burial most likely induced a pressure of about $3 \mathrm{kbar}$ and temperature of about $330^{\circ} \mathrm{C}$ (Crouzet, Ménard \& Rochette, 2001; Simon-Labric et al. 2009; Bellanger et al. 2015). In the Subalpine chains, however, where tectonic burial was probably not significant, inherited normal faults were clearly reactivated (Fig. 1; e.g. Deville et al. 1994; Roure \& Colletta, 1996; Deville \& Chauviere, 2000; Bellahsen et al. 2014).

Thus, it appears that tectonic burial may have a strong effect on the style of basin inversion, especially the reactivation of inherited normal faults. In this contribution, we performed thermo-mechanical modelling in order to investigate the role of tectonic burial, fault internal friction and geothermal gradient on normal fault reactivation and the mode of basin inversion.

\section{Geological setting}

\section{2.a. The external Western Alps}

The Western Alps orogenic system results from the closure of the Ligurian Ocean followed by the continental subduction of the distal parts of the European margin (now the internal Alpine units) and finally continental collision with Adria. The European margin was previously stretched during Liassic to Dogger times, and its upper crust is structured by extensional basins and crustal-scale normal faults (Barféty et al. 1979; Lemoine et al. 1986; Tricart \& Lemoine, 1986; de Graciansky et al. 1989). The external part of the Western Alps (the Dauphinois zone) results from the inversion of the European proximal margin during the Alpine collision phase. During this phase, starting at 30-35 Ma, this margin was buried under the internal units owing to the activation of the Penninic Frontal Thrust and then inverted (Fig. 1) (e.g. Rolland et al. 2008; Simon-Labric et al. 2009; Sanchez et al. 2011; Dumont, Schwartz \& Guillot, 2012; Bellahsen et al. 2012, 2014; Bellanger et al. 2014, 2015). The external zone consists of the External Crystalline Massifs (ECM: Argentera, Oisans, Grandes Rousses, Belledonne, Aiguilles Rouges, Mont Blanc, Aar-Gothard massifs; Fig. 1) and the Subalpine chains (Vercors, Chartreuse, Bauges, Bornes massifs; Fig. 1). The ECM were buried under the Alpine internal units to mid-crustal depth (about $10 \mathrm{~km}$ in the Oisans massif and $15 \mathrm{~km}$ in the Mont Blanc massif) reaching greenschist-facies conditions, from $300-350$ to $400{ }^{\circ} \mathrm{C}$ and $3 \mathrm{kbar}$ to $5 \mathrm{kbar}$ from south to north (Jullien \& Goffé, 1993; Kirschner, Masson \& Sharp, 1999; Crouzet, Ménard \& Rochette, 2001; Rolland et al. 2008; Boutoux et al. 2014b; Bellanger et al. 2015). It is noteworthy that the Subalpine chains did not experience much tectonic burial under the internal units, at least at the Oisans latitude (Fig. 1).

Moreover, the shortening styles of the ECM and the Subalpine chains are very different. In the ECM, the normal faults bounding inherited extensional basins show no evidence of reactivation as thrust or shear zones (Fig. 2; Tricart \& Lemoine, 1986; Bellahsen et al. 2012, 2014; Boutoux et al. 2014a). Distributed shear zones in the basement produce kilometre-scale 'basement folds' and induce vertical extrusion of the inherited extensional basins. The cover of the inherited basins is not significantly detached from the basement and is dysharmonically folded above the basement shear zones (e.g. Bourg d'Oisans and Mizoën basins, Fig. 2). On the contrary, in the Subalpine chains, a decollement level in the Liassic or Triassic series localizes the shortening in the overlying sedimentary cover (e.g. Deville et al. 1994). In these belts, inherited normal faults are inverted and connect to the decollement level in the sedimentary cover (e.g. Saint-Laurent fault, Valence fault, Fig. 2). Those decollements and inverted normal faults are connected to Miocene crustal ramps beneath the frontal ECM (e.g. Butler, 1989; Deville et al. 1994; Burkhard \& Sommaruga, 1998; Deville \& Chauvière, 2000).

\section{2.b. Oisans basin inversion}

In the ECM, two inherited extensional basins are located between the Belledonne, Grandes Rousses and Oisans massifs (Bourg d'Oisans and Mizoën basins) (e.g. Lemoine et al. 1989) (Fig. 3). They are filled with Liassic to Dogger marls and limestones. Two crustalscale normal faults (the Ornon and the Mizoën normal faults, from west to east, respectively) bound the Jurassic basins (Fig. 3; Barféty et al. 1972; Barbier et al. 1973). During the Alpine collision, these faults were not significantly reactivated (Bellahsen et al. 2012). The activation of the basement shear zones (Bellahsen et al. 2012; Bellanger et al. 2014) triggered the vertical 

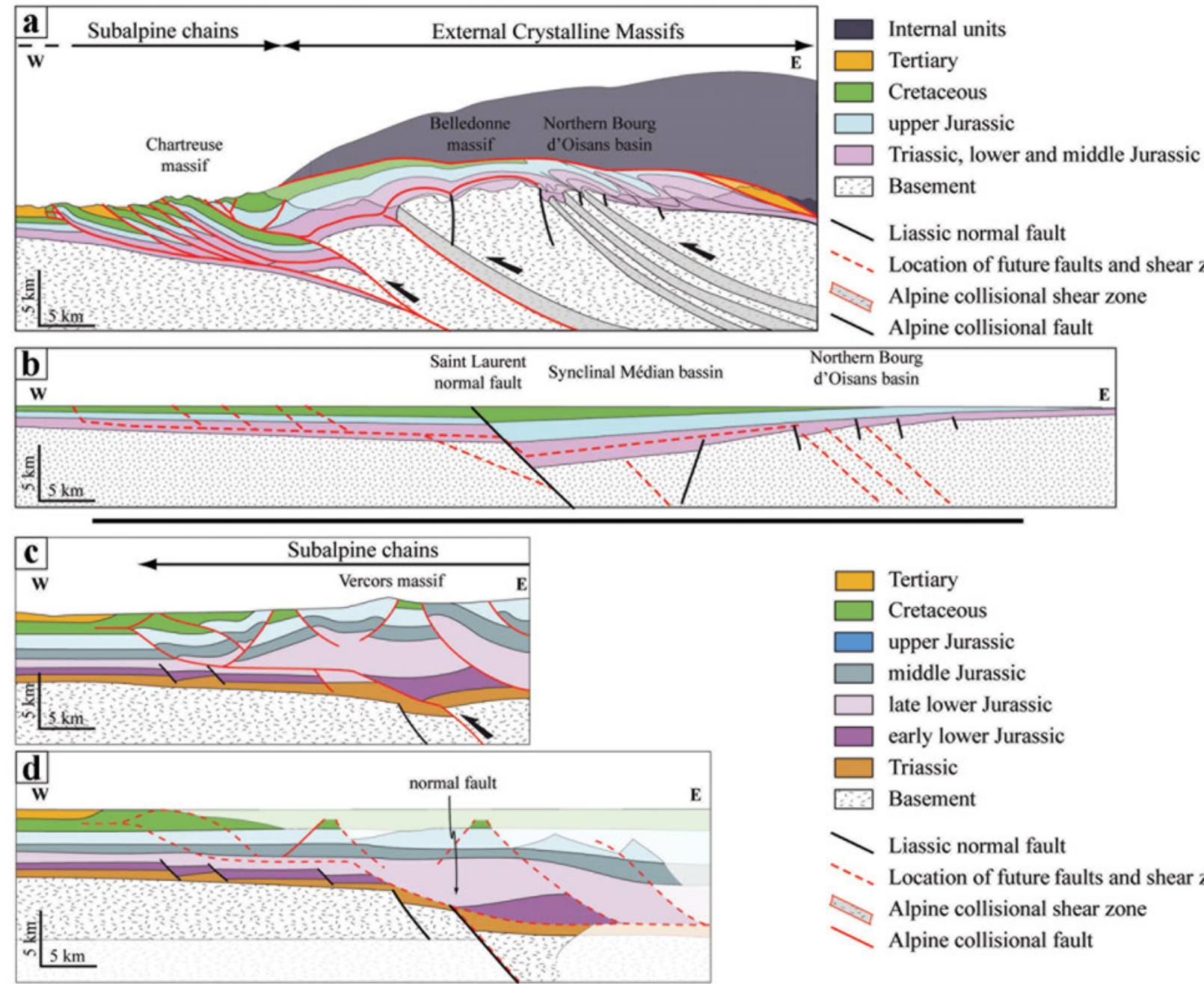

Liassic normal fault

- Location of future faults and shear zones

Alpine collisional shear zone

Alpine collisional fault

Figure 2. (Colour online) Examples from the Alps. Balanced cross-section (a) of the External Western Alps and restoration (b), at the Oisans latitude (modified from Bellahsen et al. 2014). Collisional shortening is accommodated by cover folding and thrusting above the undeformed basement in the Subalpine chains. In the ECM, basement is involved in the shortening and deformed by shear zones. Between the Subalpine chains and ECM, at the approximate front of the internal nappe units, basal decollements of the Subalpine chains connect to a crustal ramp below the ECM. (c) Balanced cross-section of the Vercors Subalpine chain and restoration (d) (modified from Roure \& Coletta, 1996). Note the reactivation of the normal faults bordering the extensional basins within the Subalpine chains while the normal faults bordering the extensional basins within the ECM are not reactivated (Bourg d'Oisans and Mizoën normal faults). See Figure 1 for location.

extrusion of the two basins while their cover was dysharmonically folded above the basement (Fig. 3) (Tricart \& Lemoine, 1986; Dumont et al. 2008; Bellahsen et al. 2012; Boutoux et al. 2014a).

In the Bourg d'Oisans basin (Fig. 3), five shear zones are recognized and did not propagate in the cover where the deformation is diffuse and characterized by synfolding cleavage (Fig. 3). The shear zones, cutting across the inherited Variscan foliation, are characterized by mylonites and phyllonites (Bellahsen et al. 2012; Bellanger et al. 2014). In the cover, five main kilometrescale N-S folds are mapped in the field (Fig. 3; Barféty et al. 1972). They are disharmonic folds, with E-dipping axial surfaces, associated with internal layer deformation (Fig. 3; Gratier \& Vialon, 1980; Boutoux et al. 2014a). In the Mizoën basin (Fig. 3), two main 'basement folds' (Dumont et al. 2008) were mapped and are interpreted as the result of intense and local- ized Alpine shearing (Bellahsen et al. 2012). The cover deformation is similar to that in the Bourg d'Oisans basin. However, the cover is slightly detached above the Emparis plateau (Fig. 3).

Two main different cleavages associated with the E-W shortening affect the cover (Fig. 3). S1 cleavage, mainly W-dipping, can be identified only close to the basement (Fig. 3). S1 is the consequence of an early top-to-the-E shearing of the basement-cover interface (Bellahsen et al. 2012; Boutoux et al. 2014a). This S1 cleavage is overprinted by a late E-dipping S2 cleavage (Fig. 3). S2 cleavage affects the whole of the basins in association with the main top-to-the-W shortening phase (Fig. 3; Dumont et al. 2008; Bellahsen et al. 2012; Boutoux et al. 2014a). A final cleavage dipping eastwards may have affected the metasedimentary cover (Gratier \& Vialon, 1980; Dumont et al. 2008). 


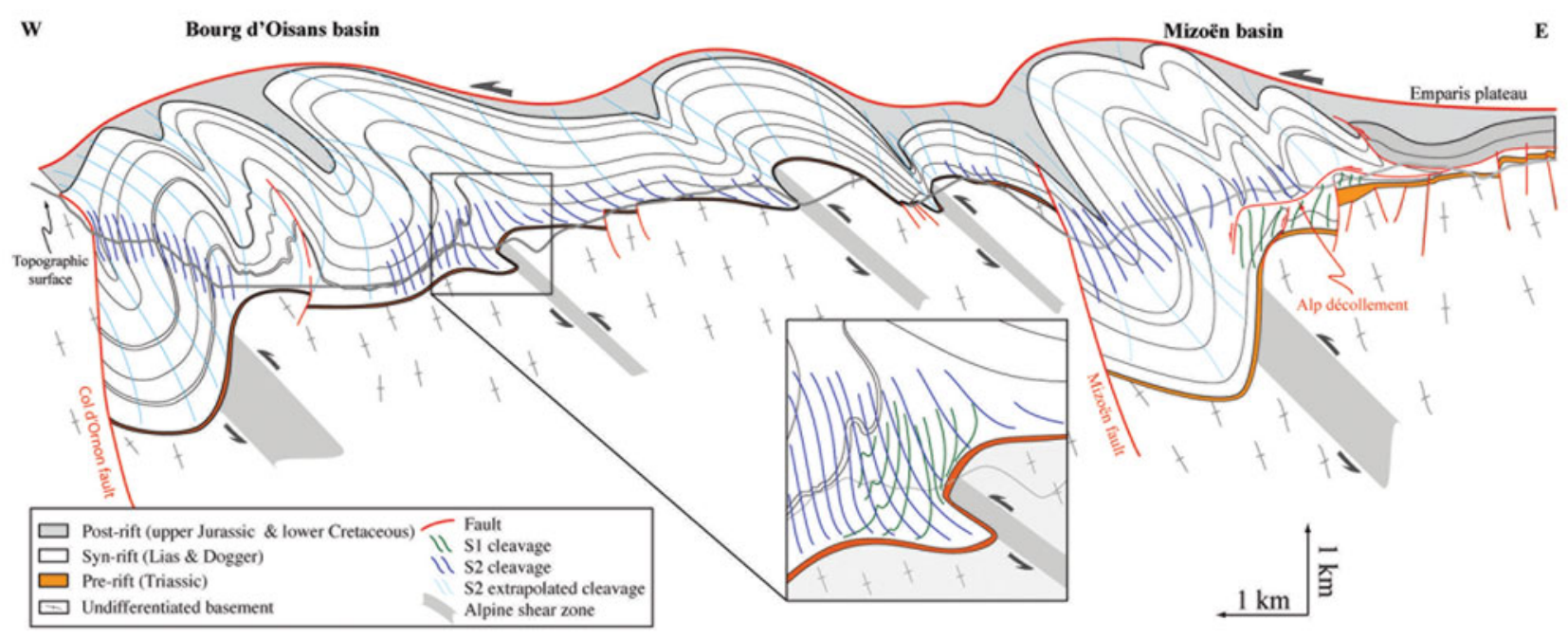

Figure 3. (Colour online) Cross-section of the Oisans inherited extensional basins (Modified from Boutoux et al. 2014a). Four shear zones in the Bourg d'Oisans basin and one in the Mizoën basin accommodate the basement shortening. The basin cover is dysharmonically folded and two main cleavages can be deciphered. S1 cleavage, generally dipping to the west, can only be seen close to the basement-cover interface and attests to an E-verging shearing. S2 cleavage, dipping to the east, is present in the entire cover and is linked to the W-verging Penninic Frontal Thrust. Note that in the Mizoën basin, S1 and S2 cleavages are segregated, respectively, below and above the Alp decollement.

\section{Thermo-mechanical modelling of half-graben inversion}

\section{3.a. Numerical method}

In this study, the numerical models were performed using GALE code (v1.6.1), a finite element code based on the Arbitrary Lagrangian Eulerian particle-in-cell method (Moresi, Dufour \& Mühlhaus, 2003). The code solves the incompressible Stokes flow for the velocity, $v$, and pressure, $\mathrm{P}$, with variable effective viscosity coefficients, $\eta_{\text {eff }}$, and variable density, $\rho$, following:

$$
\begin{gathered}
\nabla \eta_{e f f}\left(\mathbf{J}+\mathbf{J}^{\mathrm{T}}\right)-\nabla \mathrm{P}=-\rho(\mathrm{T}) \\
J=\nabla v \\
\nabla . v=0
\end{gathered}
$$

The Stokes flow solver is coupled with conservation of energy:

$$
\kappa \Delta T-v \nabla \mathrm{T}=\partial T
$$

where heat $(\mathrm{T})$ is a function of the conduction and advection through the constant thermal diffusivity $\kappa$. The computational mesh consisted of $256^{*} 64 \mathrm{Q} 1$ (bilinear) elements. Evolution in time is obtained through advection of particles (tracking lithology) and the equation of conservation of energy, with time steps limited to $10 \%$ of the Courant criterion. Passive markers were added to compute the finite strain field (Le Pourhiet et al. 2012).

We use a first-order approximation of rock rheology and approximate the ductile behaviour of rocks via a
Newtonian flow rule in which dependence on temperature follows Frank-Kamenetskii, for which the number of parameters is limited to a reference viscosity $\eta_{o}$ and a characteristic temperature $\Theta^{-1}$ in order to compute the effective viscosity $\left(\eta_{\text {eff }}\right)$ :

$$
\eta_{\mathrm{eff}}=\eta_{o} \times \exp (-\mathrm{T} \Theta)
$$

The Mohr-Coulomb yield criterion is simulated by a simplified Drucker-Prager viscoplastic flow rule, lowering the viscosity at high stress (Lemiale et al. 2008):

$$
\eta_{\text {eff }}=\min \left(\frac{\tau^{\mathrm{y}}}{2 \dot{\mathrm{I}}}, \eta_{0} \exp ^{-\theta \mathrm{T}}\right)
$$

where $\dot{I}$ is the second invariant of strain rate and $\tau^{y}$ is the yield stress computed from dynamic pressure $P$ and a material parameter including strain-dependent rock friction $\phi\left(\mathrm{E}^{p}\right)$ and cohesion $C_{0}$, following:

$$
\Gamma^{\gamma}=\sin \Phi\left(\mathrm{E}^{p}\right) P+2 C_{0} \cos \Phi\left(\mathrm{E}^{p}\right)
$$

In the models presented here, we apply plastic softening to simulate wear inside the fault. The friction coefficient $\mu=\tan (\Phi)$ in the upper and lower crust varies from 0.6 to 0.1 , with plastic strain $\left(\mathrm{E}^{p}\right)$ varying from 0 to $10^{3} \mathrm{MPa}$.

\section{3.b. Initial and boundary conditions}

We based the initial geometry of the model on published restored cross-sections for the Western Alps (Bellahsen et al. 2012; Boutoux et al. 2014a) and on non-inverted rift and half-graben geometry (e.g. Colletta et al. 1988). In order to avoid mechanical interference resulting from the complicated geometry of structures insides the model, we simplified the model 


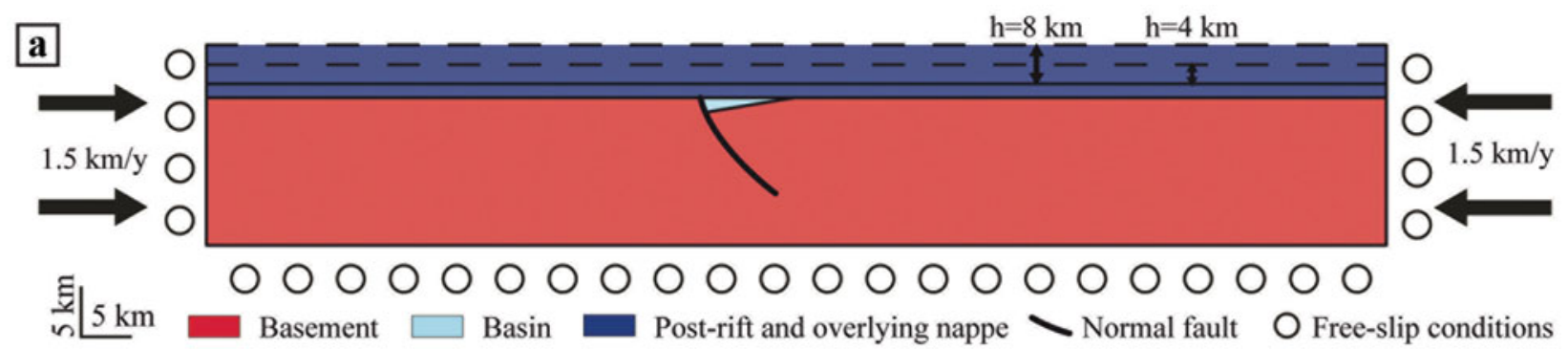

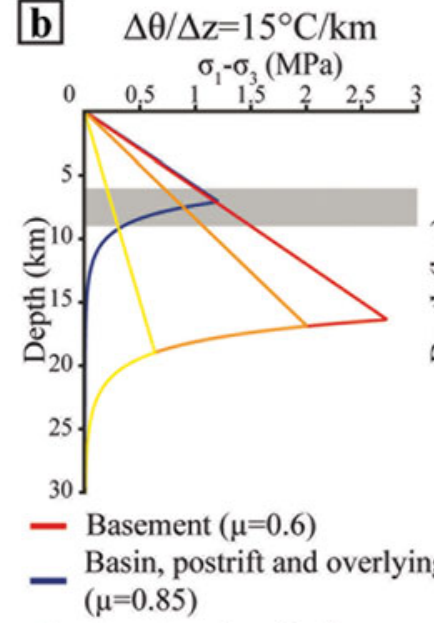

Strain rate: $\dot{\varepsilon}=6 \mathrm{e}^{-15}$

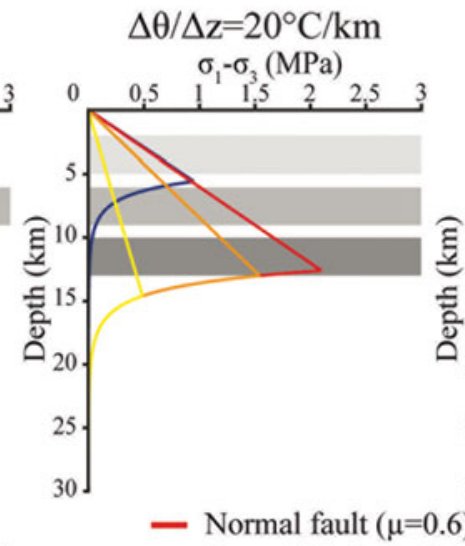

- Normal fault $(\mu=0.6)$

- Normal fault $(\mu=0.1)$

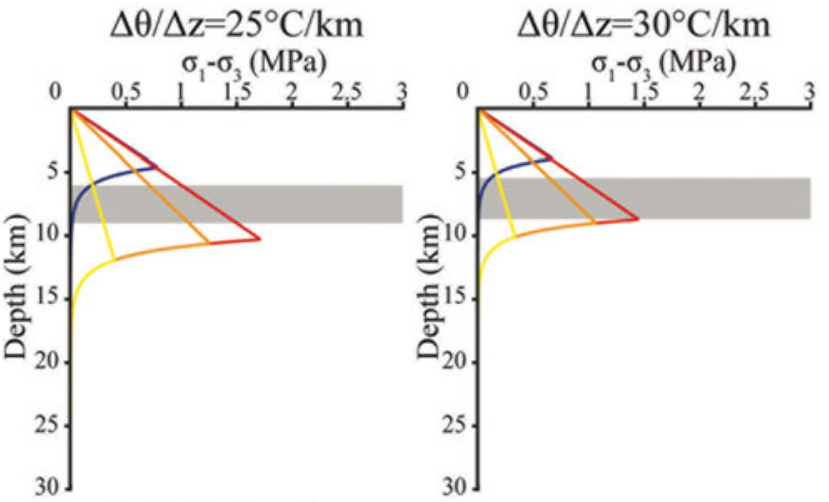

Basin depth under:

$2 \mathrm{~km}$ of post-rift

$2 \mathrm{~km}$ of post-rift and $4 \mathrm{~km}$ of overlying nappe

$2 \mathrm{~km}$ of post-rift and $8 \mathrm{~km}$ of overlying nappe

Figure 4. (Colour online) (a) Setup of the model. Thick black arrow - shortening direction on either side of the model. Dashed lines at the topside of the box represent the variation in thickness of the allochthonous nappe. The height of the model varies from $32 \mathrm{~km}$ to $40 \mathrm{~km}$. The left and the right sides represent the west and the east, respectively. (b) Strength profiles of the model. Parameters used to compute strength profiles are reported in Table 1. The depth of the basin is figured in grey.

to a single half-graben bordered by a listric normal fault and covered with a constant thin layer of postrift sediments (Fig. 4). Moreover, we implemented an overlying layer representing the allochthonous nappe of the internal units and allowing tectonic burial of the half-graben (Fig. 4a). We used passive markers to compute the total strain evolution and the direction of lineations to highlight the deformation pattern (Le Pourhiet et al. 2012). Our model is two-dimensional and therefore does not take into account oblique deformations.

We implemented two mechanical layers and a basin (Fig. 4a). We used a $240 \mathrm{~km}$ width by 32 to $40 \mathrm{~km}$ height box to avoid perturbations due to side effects at the edges of the model. The sedimentary cover consists of $2 \mathrm{~km}$ thick post-rift sediments and the nappe. We varied the thickness of the allochthonous nappe from $0 \mathrm{~km}$ to $8 \mathrm{~km}$ in order to simulate the variable tectonic burial of the basin. The basement is $30 \mathrm{~km}$ thick, except in the basin where it is thinner. We considered a $25 \mathrm{~km}$ long and $3.5 \mathrm{~km}$ deep half-graben. The basin border normal fault in the model is $1 \mathrm{~km}$ thick, and dips $70^{\circ}$ towards the east (Fig. 4). The box is subjected to a symmetrical shortening of $3.3 \mathrm{~mm} \mathrm{y}^{-1}$. We imposed free slip conditions at the lower surface and the edges of the box.

We chose an initial linear geothermal gradient of $20^{\circ} \mathrm{C} \mathrm{km}^{-1}$ across the model as indicated by thermobarometric data (Crouzet, Ménard \& Rochette, 2001; Bel- langer et al. 2015). Moreover, we considered for simplification that the system is thermally equilibrated; there is no heat provided by the base of the nappe. We also varied the geothermal gradient to test its influence on basin inversion: the geotherm was set to $15,20,25$ or $30{ }^{\circ} \mathrm{C} \mathrm{km}^{-1}$ (Fig. 4b).

Within the inherited extensional basins of the Alpine ECM, shortening is accommodated differently in the cover and in the basement. Indeed, while the basement is locally sheared, the cover is dysharmonically folded above the basement. This strongly suggests a mechanical behaviour in the cover different to that in the basement. We therefore selected creep parameters in accordance with field observations and with the geothermal gradient deduced from the metamorphic facies (greenschist facies; e.g. Jullien \& Goffé, 1993). We precomputed yield strength envelopes that account for the geometry of our models to ensure that with no burial: (1) the brittle-ductile transition of the basement/nappe occurs at $12 \mathrm{~km}$ depth and (2) the brittle-ductile transition of the syn/post-rift sediments occurs at $10 \mathrm{~km}$ depth.

The fault zone is modelled with the same creep parameters as the basement; only the friction coefficient (brittle strength) differs by varying from 0.1 to 0.6 , the strongest fault having the same friction as the basement rocks and sediments. Table 1 summarizes the mechanical and thermal parameters of each of the three lithologies. 
Table 1. Material parameters

\begin{tabular}{|c|c|c|c|c|}
\hline Material property & Units & Sediments & Crust & Fault \\
\hline Density & $\rho\left(\mathrm{kg} \mathrm{m}^{-3}\right)$ & 2400 & 2800 & 2800 \\
\hline Friction coefficient & $\mu$ & 0.85 & 0.6 & $0.6-0.1$ \\
\hline Friction coefficient after softening & $\mu$ & 0.1 & 0.1 & 0.1 \\
\hline Cohesion & $\mathrm{C}_{0}(\mathrm{MPa})$ & 10 & 10 & 10 \\
\hline Flow law & Wet quartz & Wet quartz & Wet quartz & Wet quartz \\
\hline Power-law constant ${ }^{\mathrm{a}}$ & $\mathrm{A}\left(\mathrm{s}^{-1} \mathrm{~Pa}^{-4}\right)$ & $1.1^{*} 10^{-4}$ & $1.1^{*} 10^{-4}$ & $1.1 * 10^{-4}$ \\
\hline Power-law exponent ${ }^{\mathrm{a}}$ & $\mathrm{n}$ & 4 & 3.1 & 3.1 \\
\hline Power-law activation energy ${ }^{a}$ & $\mathrm{Q}\left(\mathrm{kJ} \mathrm{mole}^{-1}\right)$ & 223 & 279 & 279 \\
\hline Reference viscosity & $\eta_{0}\left(\mathrm{~Pa} \mathrm{~s}^{-1}\right)$ & $2.64 * 10^{24}$ & $1 * 10^{27}$ & $1 * 10^{27}$ \\
\hline Characteristic temperature & $\Theta\left({ }^{\circ} \mathrm{K}\right)$ & 0.0460 & 0.0410 & 0.0410 \\
\hline Thermal diffusivity & $\kappa\left(\mathrm{m}^{2} \mathrm{~s}^{-1}\right)$ & $1 * 10^{-6}$ & $1^{*} 10^{-6}$ & $1 * 10^{-6}$ \\
\hline Linear temperature gradient & $\mathrm{T}\left({ }^{\circ} \mathrm{K} \mathrm{km}^{-1}\right)$ & $15-30$ & & \\
\hline
\end{tabular}

${ }^{\mathrm{a}}$ Flow law for wet quartz from Gleason \& Tullis (1995).

In the results, the fault zone and the basin-cover interface appear discontinuous in some models (Figs 5, 7, 8 ). With increasing deformation, the numerical method leads to the isolation of some material markers (Moresi, Dufour \& Mühlhaus, 2003) and creates heterogeneity artefacts. Thus, the exact boundaries of the layers are difficult to delimit, which therefore leads to systematic but small errors in measurements in the models.

\section{Results}

\section{4.a. Role of burial and fault friction}

We focus here on models at $2.5 \mathrm{Ma}$ after $7.2 \mathrm{~km}$ of shortening (Fig. 5). We observe in every model, except in model G, a synform of the basement below the basin. For low basin burial $\left(\mathrm{h}_{\text {burial }}=2 \mathrm{~km}\right)$ and $\mu=0.4$ to $\mu=0.1$ (Fig. 5a, d), the normal fault is reactivated and slightly steepened, along with the formation of a reverse shear zone just below the inherited fault, interpreted as a shortcut fault. At depth, drag-folds along the fault plane characterize the reactivation (Fig. 5a). The fold of the basement-cover interface in the basin and the positive inversion of the normal fault lead to the slight vertical extrusion of the basin (Fig. 5a, d). Additional top-to-the-E shear zones initiate in the normal fault hangingwall that, coupled with the normal fault reactivation, induce a pop-up structure centred on the basin (Fig. 5a, d). The cover is folded above basement antiforms with the same wavelength suggesting no decollement between the basement and cover. For higher normal fault internal friction coefficients $(\mu=0.6)$, the normal fault is as resistant as the surrounding crust ( $\mu=0.6$ in both basement and normal fault) and the basin is not inverted (Fig. $5 \mathrm{~g}$ ).

For intermediate basin burial $\left(\mathrm{h}_{\text {burial }}=6 \mathrm{~km}\right)$, the fault is slightly reactivated only for low values of $\mu$ ( $\mu=$ 0.1 ) (Fig. 5b, see the offset at the basement top) and its upper part systematically steepens for all friction values (Fig. 5b, e, h). At high friction values, the reactivation of the normal fault is inhibited and E-verging reverse shear zones develop into the fault hangingwall block inducing basement pop-up (Fig. 5e, h). The hangingwall of the normal fault is slightly folded (Fig. 5b,e, h), which leads to the steepening of the normal fault and triggers the vertical extrusion of the basin. The basin cover displays disharmonic folding above the basement folds (Fig. 5b, e, h). Moreover, we observe the extrusion of the basin cover and top-to-the-E shearing at the basement-basin contact.

For large basin burial $\left(\mathrm{h}_{\text {burial }}=10 \mathrm{~km}\right)$, the border normal fault is never reactivated whatever its internal fiction (from $\mu=0.1$ to $\mu=0.6$ ) (Fig. $5 \mathrm{c}, \mathrm{f}, \mathrm{i}$ ). The normal fault is deformed and steepened in its upper part. In the hangingwall, the basement is folded with a lower wavelength than for intermediate burial. Top-tothe-E basement shearing in the hangingwall develops only for $\mu=0.6$ (Fig. 5i). Thus, as for the intermediate burial case, the basin is vertically extruded. Disharmonic folds form in the cover above the basement fold that affects the hangingwall.

\section{4.b. Localization of shortening}

To quantify the localization of shortening at the scale of the model, we introduced a geologically relevant measurement, $R$, which is defined as the ratio of basin shortening versus model shortening. Figure 6 shows the plot of the localization of shortening (R) as a function of the internal friction of the fault $(\mu)$ in the models, for the different burial depths and geothermal gradient values.

The stronger the fault is, the more internally shortened the basin is (Fig. 6). Assuming a constant geothermal gradient, for intermediate $(\mathrm{h}=6 \mathrm{~km})$ and maximum $(\mathrm{h}=10 \mathrm{~km})$ burial values, $\mathrm{R}$ ranges from $38 \%$ to $61 \%$ (Fig. 5) and increases with the fault internal friction coefficient $(\mu)$ (Figs 5, 6). This trend is not observed for low burial values $(\mathrm{h}=2 \mathrm{~km})$ as model $\mathrm{G}$ (Fig. $5, \mathrm{~h}=2 \mathrm{~km}$ and $\mu=0.6$ ) has $\mathrm{R}$ values lower than for models A and D (Fig. $5, \mathrm{~h}=2 \mathrm{~km}, \mu=0.1$ and $\mu=0.4$, respectively). In model $\mathrm{G}$ basement, the basin and normal faults have similar internal friction coefficients and thus deformation is not localized in the basin and is distributed all over the model.

The localization of the shortening in the inherited basin increases with the geothermal gradient (Fig. 6). Indeed, $\mathrm{R}$ values in models with intermediate burial $(\mathrm{h}=6 \mathrm{~km})$ and a weak fault $(\mu=0.1)$ increase from 


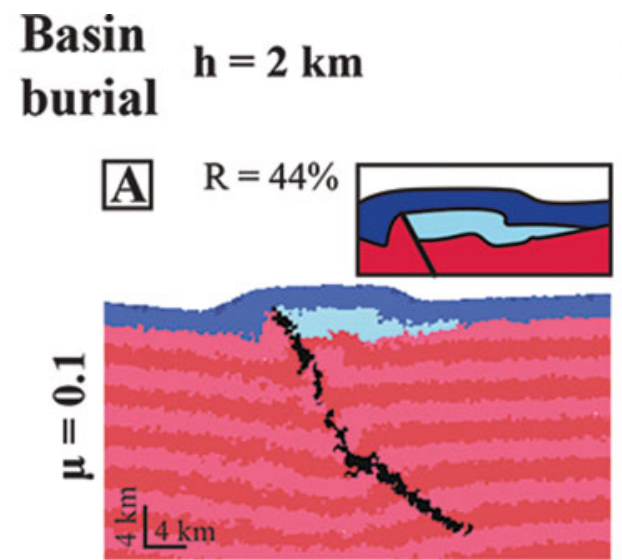

$$
\mathrm{h}=6 \mathbf{k m}
$$

$\mathrm{h}=10 \mathrm{~km} \Delta \theta / \Delta \mathrm{z}=\mathbf{2 0} / \mathrm{km}$
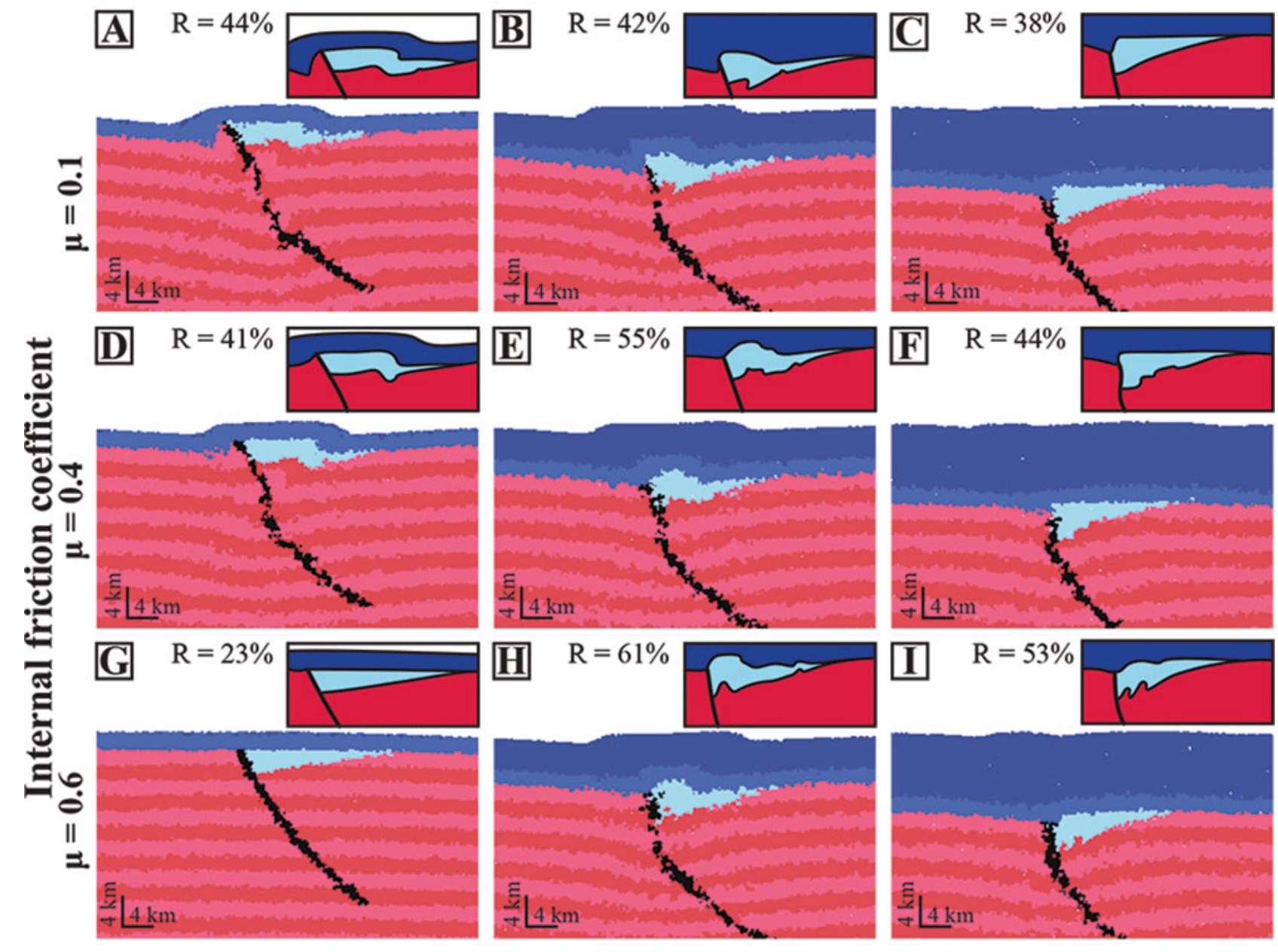

J

目
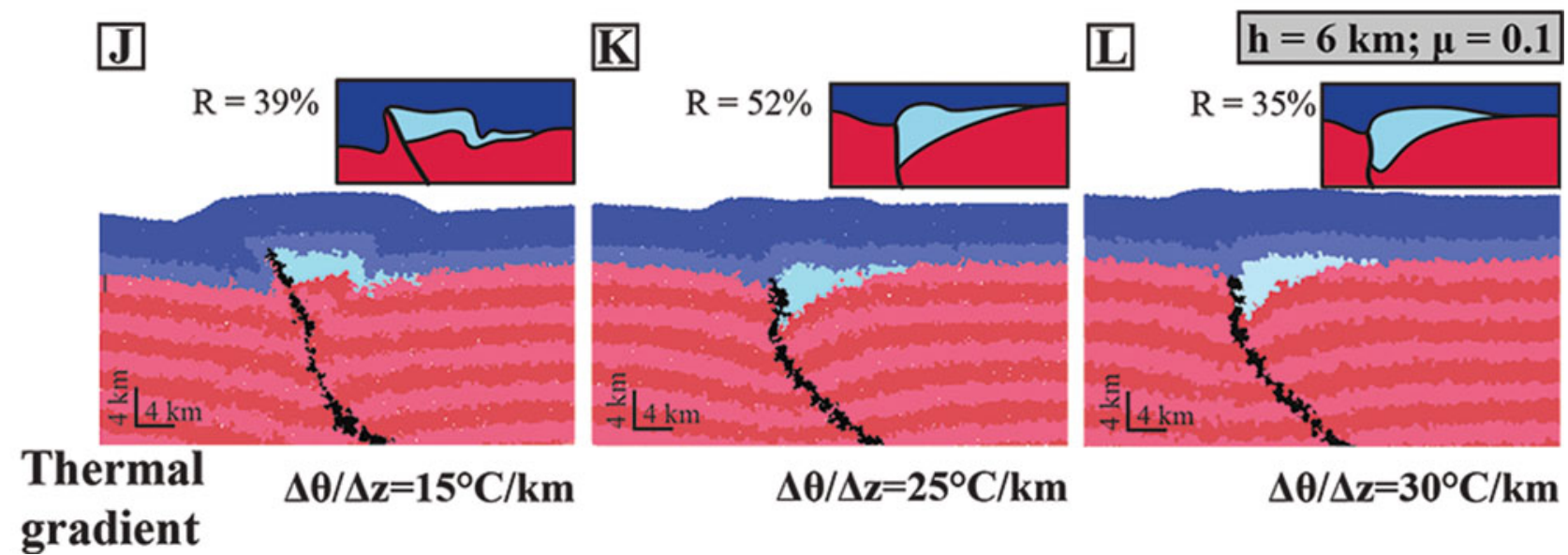

$\Delta \theta / \Delta \mathrm{z}=\mathbf{2 5 ^ { \circ }} \mathrm{C} / \mathrm{km}$

$\Delta \theta / \Delta \mathrm{z}=\mathbf{3 0}{ }^{\circ} \mathrm{C} / \mathrm{km}$

Figure 5. (Colour online) Results at $2.5 \mathrm{Ma}$, after $7.2 \mathrm{~km}$ of shortening. Zoom is on the central part of the model, including the half-graben, and interpreted sketches. From the graphic output, we compute for each model, the shortening of the basin versus the shortening of the model (R). Striped red - crust; pale blue - half-graben; medium blue - post-rift sediment; dark blue - overlying nappe. The stripes in the basement are $2 \mathrm{~km}$ wide. (Models A-I) The geothermal gradient is fixed at $20^{\circ} \mathrm{C} \mathrm{km}^{-1}$; the thickness of the overlying nappe varies from $0(\mathrm{~h}=2 \mathrm{~km})$ to $8 \mathrm{~km}(\mathrm{~h}=10 \mathrm{~km})$; the fault internal friction coefficient $(\mu)$ varies from 0.1 to 0.6 . (Models $\mathrm{J}-\mathrm{L}) \mu$ and $\mathrm{h}$ are fixed to 0.1 and $6 \mathrm{~km}$, respectively. The geothermal gradient varies from $15^{\circ} \mathrm{C} \mathrm{km}^{-1}$ to $30^{\circ} \mathrm{C} \mathrm{km}{ }^{-1}$. Note that for the deformation in model $\mathrm{G}$, the $\mu$ of the normal fault is equal to $\mu$ in the basement implying a distribution of shortening all over the model. Thus, the extensional basin is almost not inverted. 


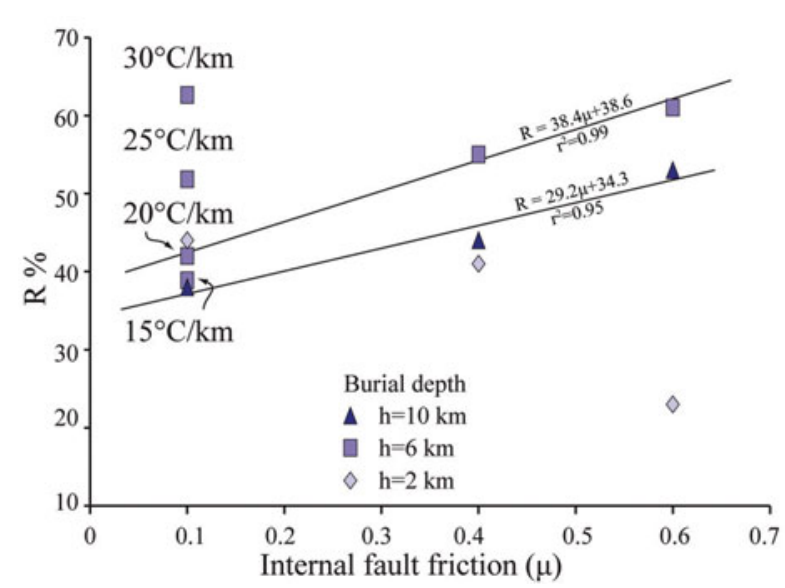

Figure 6. (Colour online) Graph of basin/model ratio of shortening $(\mathrm{R})$ versus fault internal friction coefficient $(\mu)$. Diamonds no tectonic burial $(\mathrm{h}=2 \mathrm{~km})$; squares - intermediate burial $(\mathrm{h}=$ $6 \mathrm{~km})$; triangles - large burial $(\mathrm{h}=10 \mathrm{~km})$. For $\mu=0.1$, the geothermal gradient used in the model is indicated. For every other point, geothermal gradient is $20^{\circ} \mathrm{C} \mathrm{km}^{-1}$. Note that $\mathrm{R}$ increases with geothermal gradient and $\mu$. See text for discussion.

$38 \%$ to $63 \%$ with the geothermal gradient varying from 15 to $30^{\circ} \mathrm{C} \mathrm{km}^{-1}$. For a similar geothermal gradient $\left(20^{\circ} \mathrm{C} \mathrm{km}^{-1}\right)$ and internal friction coefficient $(\mu)$, $\mathrm{R}$ is higher for intermediate burial models $(\mathrm{h}=6 \mathrm{~km})$ than for low $(\mathrm{h}=2 \mathrm{~km})$ and high burial models $(\mathrm{h}=$ $10 \mathrm{~km}$ ) (Figs 5, 6). Localization at the basin level is linked to the rheological contrast between the different layers (overlying nappe and post-rift, basin, basement at the structural level of the basin, and basement below the basin). Note the exception of model A ( $\mu=0.1, h$ $=2 \mathrm{~km}$; Fig. 5), which presents an $\mathrm{R}$ value higher than model B $(\mu=0.1, \mathrm{~h}=6 \mathrm{~km}$; Fig. 5$)$.

\section{4.c. Basin internal deformation}

Finite deformation and stretching lineations in the basin after 2.5 Ma of shortening are displayed for three values of burial $(\mathrm{h}=2 \mathrm{~km}, \mathrm{~h}=6 \mathrm{~km}$ and $\mathrm{h}=10 \mathrm{~km})$ with a fixed value of the friction coefficient of the fault $(\mu=$ 0.1) (Fig. 7).

When burial is low $(\mathrm{h}=2 \mathrm{~km})$, finite strain is high (above 1) in two shear zones (Fig. 7a, d). The Wverging thrust, located at the inherited normal fault or slightly below, has an offset higher than $2 \mathrm{~km}$. This shear zone is interpreted as a shortcut fault. The Everging back-thrust accommodates lower amounts of shortening. These two shear zones root at depth in the inherited normal fault that is reactivated as a kilometrethick shear zone. No important deformation is recorded outside these shear zones (finite strain around 0 , Fig. 7a), except in the lower part of the model where the deformation is distributed on the drag-folds along the fault plane (finite strain between 0.2 and 0.66 ).

For an intermediate burial value $(\mathrm{h}=6 \mathrm{~km})$, the deformation in the basin cover is more distributed (finite strain between 0.3 and 1) (Fig. 7b, e). At the basementcover interface, for both the hangingwall and footwall, lineations plunge around $45^{\circ}$ and attest to opposite senses of shear (E- and W-verging shears, respectively). Yet except for these shear zones, deformation is low as finite strain is around 0.3 . Moreover, two shear zones with opposite senses of shear can be deciphered in the overlying nappe. These shear zones are very similar to the ones described above for a low value of burial and root under the basin into the inherited normal fault (Fig. 7b, e). In the basement, the inherited normal fault is not reactivated (finite strain between 0 and 0.3 ) while both the hangingwall and footwall are slightly folded. These folds are due to low W-verging shearing of the hangingwall and low E-verging shearing of the footwall (finite strain around 0.4; Fig. 7b, e).

For a high burial value $(\mathrm{h}=10 \mathrm{~km})($ Fig. $7 \mathrm{c}, \mathrm{f})$, the deformation in the basin cover is also distributed (finite strain between 0.5 and 1.3). Yet, the shortening localizes at the basement-cover interface, where it is more important than for intermediate values of burial. Indeed, finite strain ranges from around 1.3 in the hanging wall to around 0.5 in the footwall (Fig. $7 \mathrm{c}$ ). As for the intermediate burial value, the basement is slightly folded owing to two conjugate $\mathrm{E}$ - and $\mathrm{W}$-verging shear zones. Shearing is more intense and more distributed in the hangingwall than in the footwall. Finite strain ranges between 0.3 and 0.5 and shear zones are $4 \mathrm{~km}$ to $6 \mathrm{~km}$ thick in the hangingwall while finite strain ranges between 0.2 and 0.3 and shear zones are $2 \mathrm{~km}$ to $3 \mathrm{~km}$ thick in the footwall. Finally, the inherited normal fault is not reactivated, as finite strain is about zero along it (Fig. 7c, f).

\section{4.d. Effect of the geotherm on the style of inversion}

The initial geothermal gradient ranges from $15^{\circ} \mathrm{C} \mathrm{km}^{-1}$ to $30^{\circ} \mathrm{C} \mathrm{km}^{-1}$ and the brittle-viscous transition in the crust and in the cover varies accordingly (Fig. 4). As a consequence, with the warmest geothermal gradient (from $20^{\circ} \mathrm{C} \mathrm{km}^{-1}$ to $30^{\circ} \mathrm{C} \mathrm{km}^{-1}$ ), the basin is weaker than the basement at the structural level of the basin.

The effective viscosity $\left(\eta_{\text {eff }}\right)$ is a function in the model of the minimum of the simplified DruckerPrager viscoplastic and the Frank-Kamenetskii equation flow rules (eq. 6). Variations of $\eta_{\text {eff }}$ are due to the geothermal gradient, to I (the second invariant of the strain rate tensor) and to the dynamic pressure, $P$ (eq. 7).

Figure 8 shows isocontours of $\eta_{\text {eff }}$ (Fig. 8 left column) and the strain rate for the corresponding models (Fig. 8 right column), after $2.5 \mathrm{Ma}$ of shortening. In Figure 8a, the internal friction coefficient and geothermal gradient are fixed $\left(0.1\right.$ and $20^{\circ} \mathrm{C} \mathrm{km}^{-1}$, respectively). In Figure 8b, the internal friction coefficient and burial are fixed ( 0.1 and $6 \mathrm{~km}$, respectively). Results show the basement folding around the extensional basin inducing a pop-down of the model centred on the basin. $\eta_{\text {eff }}$ values drop at the basement-cover interface for intermediate $(\mathrm{h}=6 \mathrm{~km}$, Fig. $8 \mathrm{a}$, model B) and high burial conditions ( $\mathrm{h}=10 \mathrm{~km}$, Fig. $8 \mathrm{a}$, 


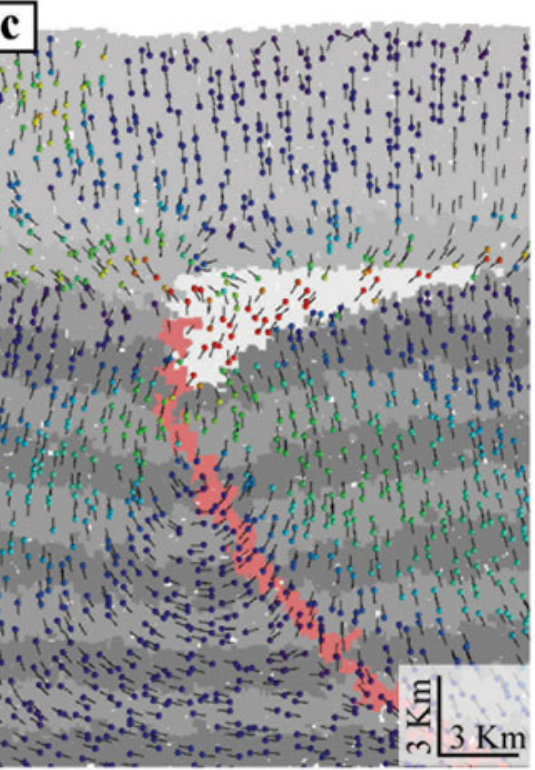

$3 \mathrm{Km} 3 \mathrm{sin}^{2}$

A

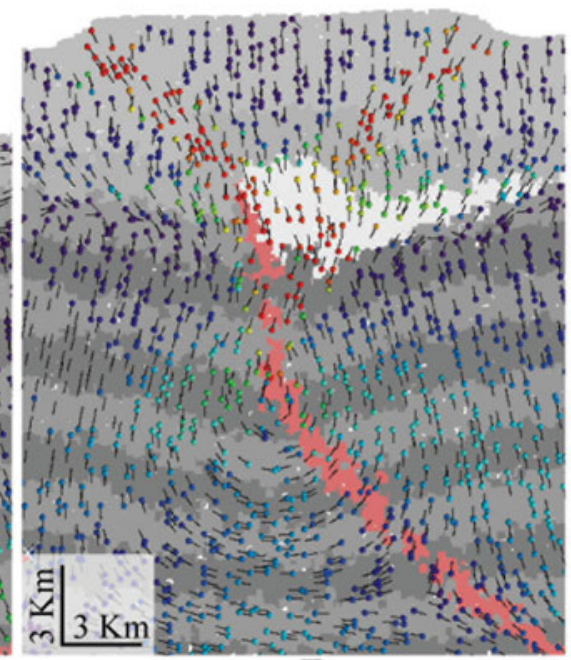

Plunge of lineation

C
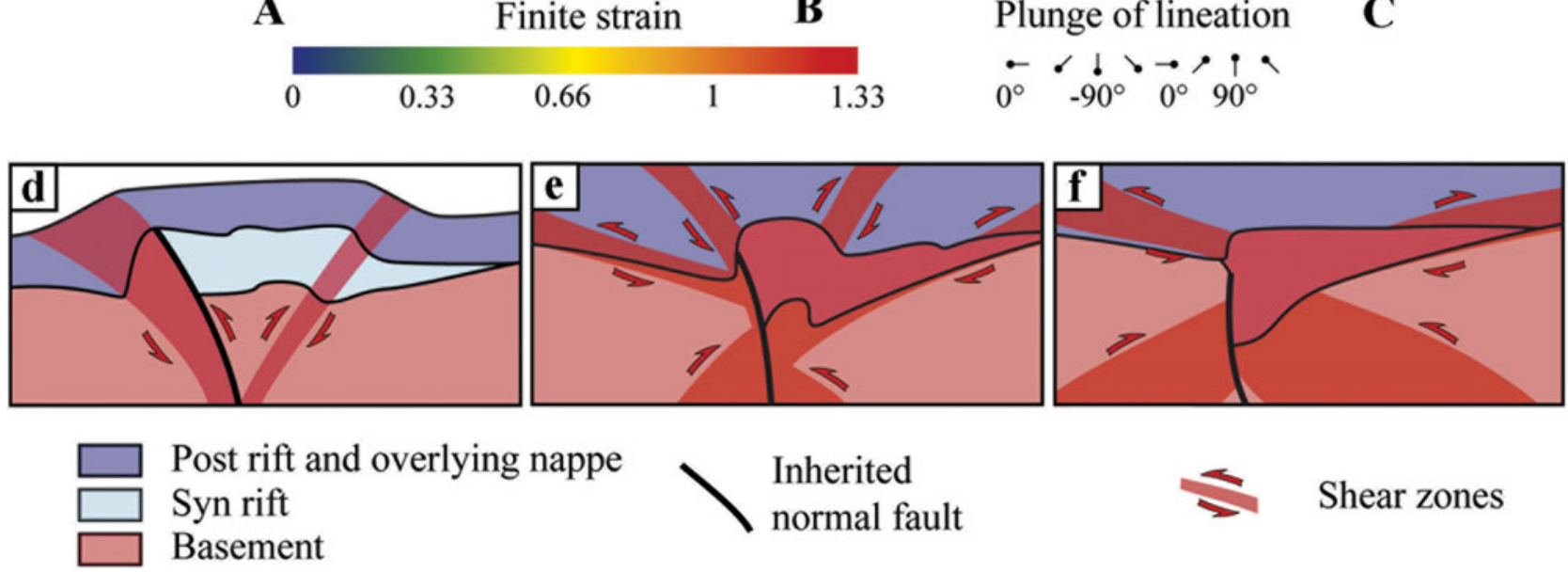

Figure 7. (Colour online) Basin shortening. (a-c) Zoom in on the basin at $2.5 \mathrm{Ma}$ after $7.2 \mathrm{~km}$ of shortening. Coloured dots indicate the finite strain intensity recorded on each marker. The bars represent the lineation. Grey stripes are passive markers and witness the finite crustal deformation. The stripes in the basement are $2 \mathrm{~km}$ wide. Model names (A, B and C) correspond to model names in Figure 5. Geothermal gradient is $20^{\circ} \mathrm{C} \mathrm{km}^{-1}$, fault internal friction coefficient is $\mu=0.1$ and burial is low for model A (h $\left.=2 \mathrm{~km}\right)$, intermediate for model B $(\mathrm{h}=6 \mathrm{~km})$ and high for model C $(\mathrm{h}=10 \mathrm{~km})$. $(\mathrm{d}-\mathrm{f})$ Corresponding interpretative sketches. From (d) to (f), the normal fault reactivation is inhibited, the shortening is more distributed, the basement-cover interface more sheared and the basin more extruded.

model C). A similar drop can be deciphered for the intermediate geothermal gradient $\left(25^{\circ} \mathrm{C} \mathrm{km}^{-1}\right.$, Fig. $8 \mathrm{~b}$, model $\mathrm{K})$ and for the high geothermal gradient $\left(30^{\circ} \mathrm{C}\right.$ $\mathrm{km}^{-1}$, Fig. $8 \mathrm{~b}$, model L). This $\eta_{\text {eff }}$ drop indicates the presence of a potential decoupling of the cover from the basement. For intermediate and high burial models and for intermediate and high geothermal gradient, $\eta_{\text {eff }}$ values in the extensional basin are lower than into the basement for similar depths (Fig. 8, models B, C, K and $\mathrm{L}$ ).

The style of basin inversion deformation for models with increasing burial depth and constant geothermal gradient (models A to C, Fig. 8a) evolves like models with increasing geothermal gradient and constant burial depth (models J to K, Fig. 8b). In the models A $\left(\mu=0.1, \mathrm{~h}=2 \mathrm{~km}, 20^{\circ} \mathrm{C} \mathrm{km}^{-1}\right.$; Fig. $\left.8 \mathrm{a}\right)$ and $\mathrm{J}(\mu=$ $0.1, \mathrm{~h}=6 \mathrm{~km}, 15^{\circ} \mathrm{C} \mathrm{km}^{-1}$; Fig. $\left.8 \mathrm{~b}\right)$, deformation is localized along the reactivated normal fault and along an E-verging shear zone in the basin.

Model B ( $\mu=0.1, \mathrm{~h}=6 \mathrm{~km}, 20^{\circ} \mathrm{C} \mathrm{km}^{-1}$; Fig. 8a) behaves similarly to models $\mathrm{J}\left(\mu=0.1, \mathrm{~h}=6 \mathrm{~km}, 15^{\circ} \mathrm{C}\right.$ $\mathrm{km}^{-1}$; Fig. $\left.8 \mathrm{~b}\right)$ and $\mathrm{K}\left(\mu=0.1, \mathrm{~h}=6 \mathrm{~km}, 25^{\circ} \mathrm{C} \mathrm{km}^{-1}\right.$; Fig. 8 b) as the basin localized the deformation in the three models. $\eta_{\text {eff }}$ values are high in the basement at the basin depth and strongly decrease into the basin (Fig. 8, models B, J, K). The fault footwall is folded, which triggers the clockwise rotation of the normal fault. In the models B and J, effective viscosity is at a minimum and strain rate values are high indicating the deformation distribution into the extensional basin. The drop in effective viscosity and the high strain rate values along the basin and basement interfaces in both the fault footwall and hangingwall indicates that those interfaces are sheared as suggested. Note that in model 

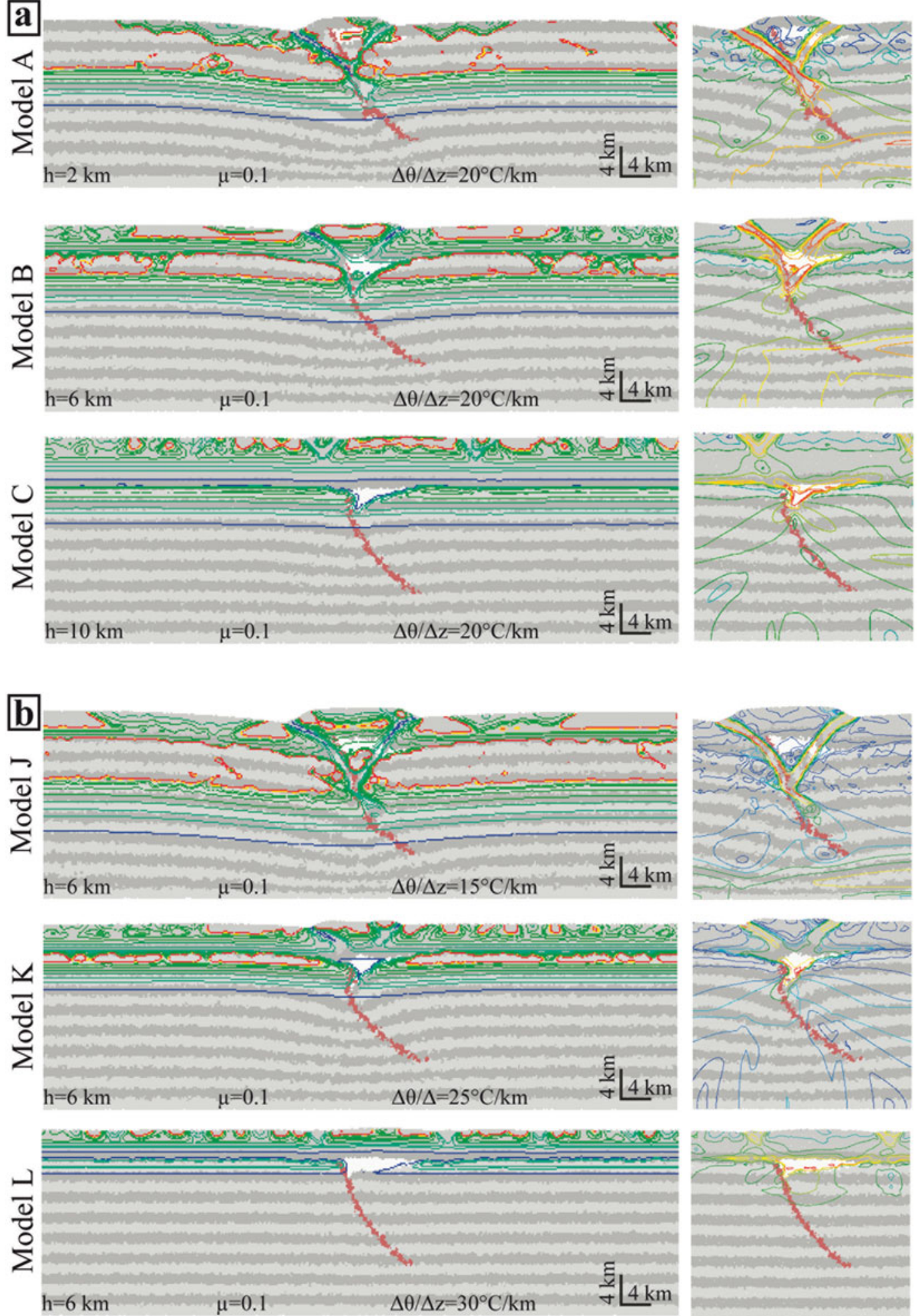

\section{Effective viscosity $\eta_{\mathrm{eff}}$ (Pa.s)}

$1.10^{-20}$

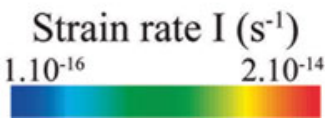

Figure 8. (Colour online) Viscosity and strain rate. Left: Isocontours of effective viscosity ( $\left.\eta_{\text {eff }}\right)$ at $2.5 \mathrm{Ma}$ and $7.2 \mathrm{~km}$ of shortening. As $\eta_{\text {eff }}$ depends on both the deviatoric stress and the strain rate, the isocontours are a proxy for the strength of materials at each time step. Note the important decrease of $\eta_{\text {eff }}$ in conjugated shear zones. Right: Isocontours of strain rate (I). Close up of the basin at $2.5 \mathrm{Ma}$ and $7.2 \mathrm{~km}$ of shortening. (a) Effect of burial: internal friction coefficient $(\mu)$ and geothermal gradient $(\Delta \theta / \Delta z)$ are fixed to 0.1 and $20^{\circ} \mathrm{C} \mathrm{km}^{-1}$, respectively. Model A: no tectonic burial $(\mathrm{h}=2 \mathrm{~km})$; Model B: intermediate burial $(\mathrm{h}=6 \mathrm{~km})$; Model C: large burial $(\mathrm{h}$ $=10 \mathrm{~km}$ ). (b) Effect of geothermal gradient: internal friction coefficient $(\mu)$ and tectonic burial are fixed to 0.1 and $6 \mathrm{~km}$, respectively. Model J: low geothermal gradient $\left(15^{\circ} \mathrm{C} \mathrm{km}^{-1}\right)$; Model $\mathrm{K}$ : intermediate geothermal gradient $\left(25^{\circ} \mathrm{C} \mathrm{km}^{-1}\right)$; Model L: high geothermal gradient $\left(30^{\circ} \mathrm{C} \mathrm{km}^{-1}\right)$. 
$\mathrm{J}$, the shear zone is localized into the basin and not at the basin and basement interface level.

Models $\mathrm{C}\left(\mu=0.1, \mathrm{~h}=10 \mathrm{~km}, 20^{\circ} \mathrm{C} \mathrm{km}^{-1}\right.$, Fig. 8a) and $\mathrm{L}\left(\mu=0.1, \mathrm{~h}=6 \mathrm{~km}, 30^{\circ} \mathrm{C} \mathrm{km}^{-1}\right.$, Fig. $\left.8 \mathrm{~b}\right)$ are similar. The viscosity contrast between the extensional basin and the basement at similar depths is significantly lower than other models (Fig. 8). In models C and L, the basement is folded around the extensional basin and the normal fault is straightened. Deformation is localized at the basin and basement interface yet strain rate values along these interfaces are lower than for models B $\left(\mu=0.1, \mathrm{~h}=6 \mathrm{~km}, 20^{\circ} \mathrm{C} \mathrm{km}^{-1}\right.$; Fig. $\left.8 \mathrm{a}\right)$ and $\mathrm{K}\left(\mu=0.1, \mathrm{~h}=6 \mathrm{~km}, 25^{\circ} \mathrm{C} \mathrm{km}^{-1}\right.$; Fig. $\left.8 \mathrm{~b}\right)$.

\section{Discussion}

\section{5.a. Role of burial depth and geothermal gradient.}

Our results highlight that the inversion of inherited basins (i.e. reactivation of the normal faults, deformation of the basement and basin vertical extrusion) is controlled by three different factors: the fault internal friction, the crustal thermicity and the basin burial depth. The influence of fault friction is dominant at shallow depths and for cold geothermal gradients as the fault constitutes the main strength contrast at the basin depth. This influence decreases rapidly at depth and with increasing geothermal gradient. As suggested by our numerical models and Buiter \& Pfiffner (2003), the normal fault localizes the deformation when the fault is weak $(\mu=0.1)$ and the basin is as strong as the basement (Figs 5, 6). The basin becomes gradually more difficult to invert as the strength of the fault increases. As suggested by our models and by Nilfouroushan et al. (2013), block rotations in the uppermost basement prevent the reactivation of extensional faults.

The depth of the brittle-ductile transition for the sediment rheology is above the depth of the brittleductile transition for the basement rheology. It places the depth of the brittle-ductile transition for the sediment rheology at the structural level of the extensional basin for intermediate to high values of geothermal gradient and for intermediate to high values of burial (Fig. 4). For those input parameters, there is a strength contrast between the basin and the basement, which favours shortening localization in the basin. Increasing the burial depth or the geothermal gradient leads to weakening the inherited basin and the basement but preserves a stronger basement at the structural level of the basin (Fig. 4). As in Bauville \& Schmalholz (2015), the contrast in viscosity between the sediments in the basin and the basement triggers the folding of the basement below the basin and its vertical extrusion. The strength contrast between the basement and the basin therefore controls the style of deformation.

Figure 9 highlights how the inversion style of the inherited basin is controlled by rheological contrast between the basin and its basement. Initial integrated strengths of different structural levels were computed for different geotherms $\left(15^{\circ} \mathrm{C} \mathrm{km}^{-1}, 20^{\circ} \mathrm{C} \mathrm{km}^{-1}, 25^{\circ} \mathrm{C}\right.$ $\mathrm{km}^{-1}$ and $\left.30^{\circ} \mathrm{C} \mathrm{km}^{-1}\right)$ and burial depths $(2 \mathrm{~km}, 6 \mathrm{~km}$ and $10 \mathrm{~km})($ Fig. 4b). In Figure 9a, we define four structural levels: a nappe and post-rift layer $\left(S_{n}\right)$, basin $\left(\mathrm{S}_{\mathrm{b}}\right)$, basement at the structural level of the extensional basin $\left(\mathrm{S}_{\text {sup }}\right)$ and basement $\left(\mathrm{S}_{\text {inf }}\right)$ below the basin. In Figure $9 b, S_{\text {sup }} / S_{b}$ is plotted versus $S_{n} / S_{\text {inf. }} . S_{n} / S_{\text {inf }}$ is the strength contrast between the overlying nappe (and post-rift layer) and the crust below the basin. $\mathrm{S}_{\text {sup }} / \mathrm{S}_{\mathrm{b}}$ is the strength contrast between the basin and the basement at similar depth and is a proxy for the weakening effect of the basin.

The results suggest that there is a positive relationship between the two ratios (Fig. $9 b$ ). For each $\mathrm{S}_{\text {sup }} / \mathrm{S}_{\mathrm{b}}$ and $S_{n} / S_{\text {inf }}$ point in the graph, we also provide corresponding interpretative sketches for models with $\mu=$ 0.1 (Fig. 9b, models A, B, C, J, K, L). The differences between the sketches clearly show that the evolution of the style of basin inversion is controlled by both ratios.

For low values of $\mathrm{S}_{\text {sup }} / \mathrm{S}_{\mathrm{b}}(<1)$ and $\mathrm{S}_{\mathrm{n}} / \mathrm{S}_{\text {inf }}(<0.2)$ (Fig. 9b, models $\mathrm{A}$ and J), the rheological contrast between the basin and the basement at the same structural level is very low and the nappe + post-rift layer is weaker than the basement. The inversion style is characterized by localized shearing along the normal fault, the associated shortcut fault and along an E-verging shear rooting in the basement and cutting across the basin.

With higher values of $\mathrm{S}_{\text {sup }} / \mathrm{S}_{\mathrm{b}}(>1)$ and $\mathrm{S}_{\mathrm{n}} / \mathrm{S}_{\mathrm{inf}}(<1)$ (Fig. 9b, models B and $\mathrm{K}$ ), there is a significant rheological contrast between the basin and the basement at the same structural level while the nappe + post-rift layer remains weaker than the basement below the basin. The folding of the basement and the inhibition of normal fault reactivation leads to the vertical extrusion of the basin (Fig. 9b, model K). The deformation in model K is more distributed than in model B (Fig. 9b).

For $\mathrm{S}_{\mathrm{n}} / \mathrm{S}_{\mathrm{inf}}>1$, the nappe layer is stronger than the basement below the basin, which leads to distribution of the deformation all over the model; conversely the inherited basin accommodates less shortening. Therefore, the localization of the shortening in the model (R) is lower for $\mathrm{h}=10 \mathrm{~km}$ models than for $\mathrm{h}=6 \mathrm{~km}$ models (Fig. 5; models C, F, I versus models B, E, H).

\section{5.b. Normal fault reactivation}

The normal fault reactivation is inhibited in models with a hot geothermal gradient (Fig. 5, models K, L) and high burial depth (Fig. 5, models C, F, H and I). Thus, two parameters control this process. (1) The strength contrast between the inherited basin and the basement at the same structural level. Indeed, high burial depth and high geothermal gradient tend to decrease the strength contrast between the weak fault and the basement inhibiting normal fault reactivation. (2) The basement folds near the extensional basin rotate the normal fault in our models and in Nilfouroushan et al. (2013). The rotation of the normal fault, linked to the basement distributing the deformation, increases the dip of shearing along the normal fault and thus tends 

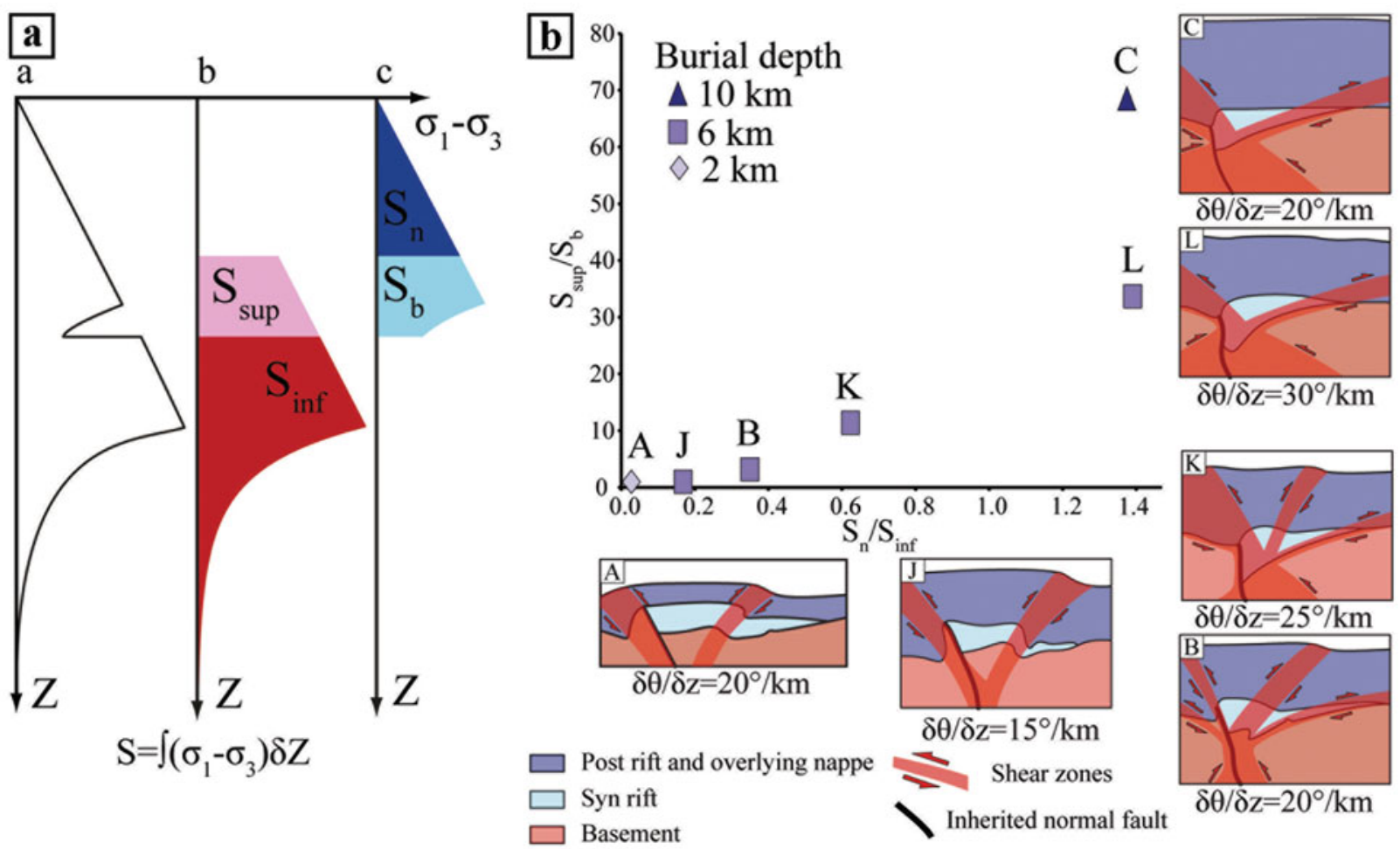

$\delta \theta / \delta z=20^{\circ} / \mathrm{km}$

Figure 9. (Colour online) Influence of crustal rheology on the inherited normal fault reactivation. (a) Strength profiles of the models. $\mathrm{a}$ - total strength envelope of the model when a basin is present; $\mathrm{b}$ - strength envelope of the basement when no basin is present; $\mathrm{c}$ - strength envelope of the cover (overlying nappe, post-rift layer and half-graben syn-rift layer); $\mathrm{S}_{\mathrm{n}}-$ strength of the post-rift and overlying nappe unit; $S_{b}$ - strength of the basin; $S_{\text {sup }}$ - strength of the upper basement layer when no basin is present; $S_{\text {inf }}-$ strength

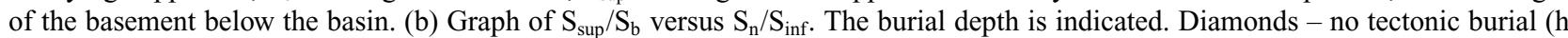
$=2 \mathrm{~km})$; squares - intermediate burial $(\mathrm{h}=6 \mathrm{~km})$; triangles - large burial $(\mathrm{h}=10 \mathrm{~km})$. The geothermal gradient is indicated below each sketch. Model names are from Figure 5. For all model sketches $\mu=0.1$.

to inhibit its reactivation (see Bonini, Sani \& Antonielli, 2012 and references therein for similar inhibition of normal fault reactivation due to rotation).

\section{5.c. Comparison with the Alpine collision}

In the models, we assumed a constant (laterally and through time) thickness of the overlying nappe. This is an oversimplification as ECM burial depth increases from east to west (Bellahsen et al. 2012; Bellanger et al. 2015) and through time between the onset of nappe emplacement and the burial peak. However, most of the deformation in the ECM is estimated to have occurred at or close to the metamorphic peak (e.g. Rolland et al. 2003; Cenki-Tok et al. 2013; Bellanger et al. 2015).

Bonnet et al. (2007) studied the Alpine collision with the help of analogue models and proposed that most of the basement thrusts were reactivated inherited normal faults. The in-sequence propagation of the shortening, as proposed in Burkhard \& Sommaruga (1998), is indeed the in-sequence propagation of the reactivation of inherited extensional structures. As in our numerical modelling, inherited normal faults were modelled as a thin layer with a weaker rheology than the surrounding basement and were buried under several kilometres of overlying nappe. Therefore, the major difference between the two modelling methodologies is the influence of temperature.
Based on these results, we propose a direct relationship between the style of basin inversion and the depth of burial in the external Western Alps (Fig. 10). In the Subalpine chains, collisional shortening is partly accommodated by the inversion of the inherited extensional basin. Those basins were not tectonically buried under the internal Alpine units and show reverse reactivation of their border normal fault (Fig. 10a, b). In the ECM, the Liassic inherited extensional basins localized the collisional shortening. Indeed, those basins weakened the crust during its burial (Bellahsen et al. 2012). Thus, with burial and heating, ECM basins were extruded owing to the development of basement antiforms linked to basement shear zone development and normal fault reactivation inhibition (Fig. 10c). Good examples of such inverted basins are the inherited basins in the Oisans massif and surrounding area (Fig. 10c) and other Alpine ECM (e.g. the Chamonix basin; Gillcrist, Coward \& Mugnier, 1987; Boutoux et al. 2014a).

At a first order, in the ECM inherited basins, there is no decollement between the cover and basement. However, disharmonic deformation of the cover above basement folds suggests short local decollements and shearing of the cover over the basement (e.g. Burkhard, 1988; Escher, Masson \& Steck, 1993; Boutoux et al. 2014a). In our models, the cover is progressively extruded from the basin and the basement-cover interface 


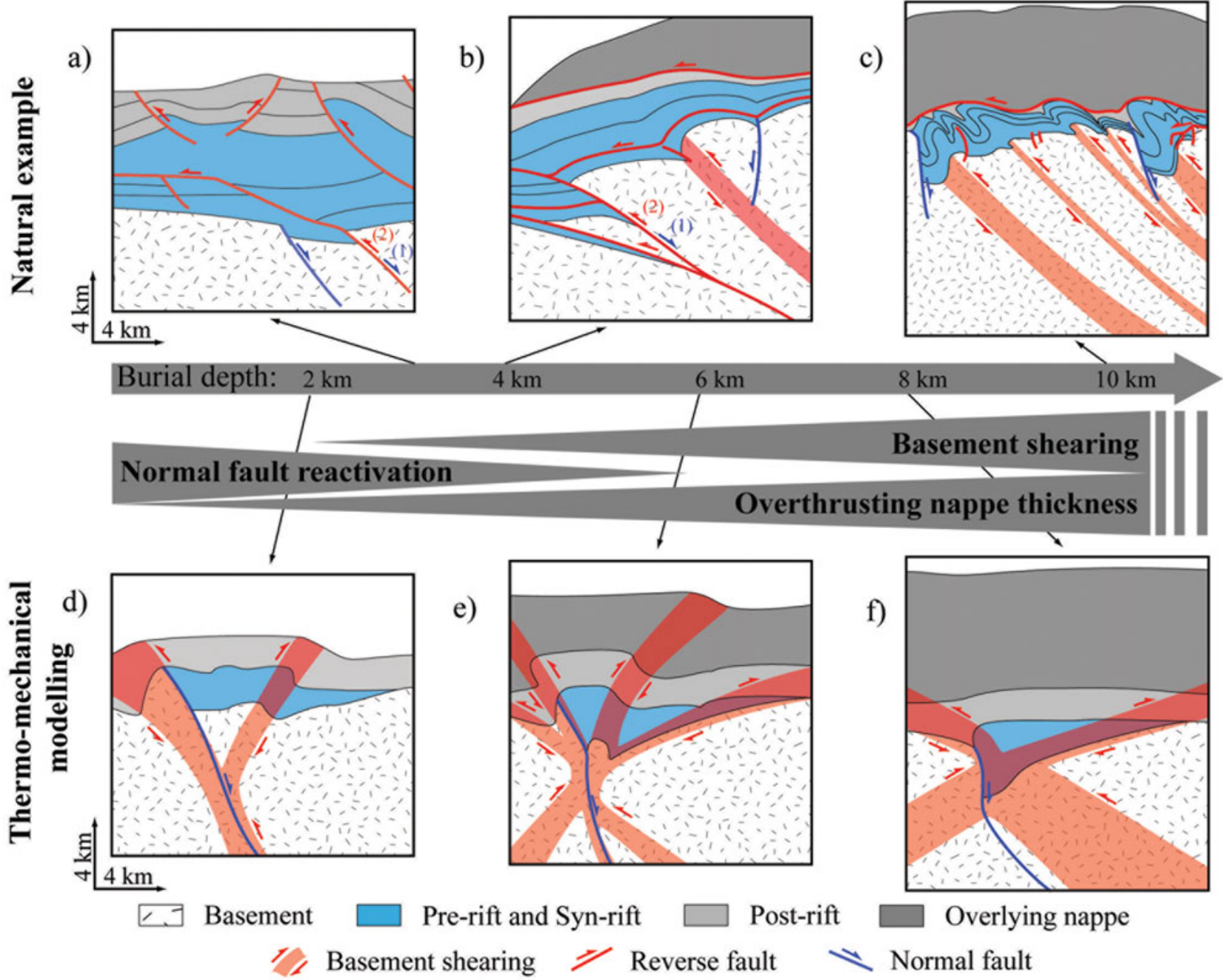

Figure 10. (Colour online) Synthesis of inversion style of inherited extensional basins as a function of their tectonic burial based on the comparison between the Western Alps and thermo-mechanical modelling. (a-c) Natural examples taken from balanced crosssections in the external zones of the Western Alps (see Figs 2, 3). (a) Cross-section of the Vercors Subalpine chain (modified after Roure \& Coletta, 1996). Inherited basin was not tectonically buried and crustal shortening is accommodated by inherited normal fault reactivation. (b) Cross-section of the Saint-Laurent basin buried at 0 to $5 \mathrm{~km}$ (modified after Bellahsen et al. 2014). Crustal shortening is accommodated partially by inherited normal fault reactivation and by basement shearing. (c) Cross-section of the Oisans basins buried at $10 \mathrm{~km}$ depth (modified after Boutoux et al. 2014a). Normal faults are steepened and not reactivated, crustal shortening is accommodated by basement shearing. (d-f) Thermo-mechanical modelling results after $2.5 \mathrm{Ma}$ and $7.5 \mathrm{~km}$ of shortening. (d) The basin is buried under $2 \mathrm{~km}$ of post-rift sedimentary rocks. The inherited normal fault is reactivated and back-thrust/shear zones initiated. (e) The basin is buried under $2 \mathrm{~km}$ of post-rift sediments and $4 \mathrm{~km}$ of overlying nappe. The normal fault is slightly reactivated but crustal shortening is essentially accommodated by back-thrust/shear zones, propagating in the cover. (f) The basin is buried under $2 \mathrm{~km}$ of post-rift sediments and $8 \mathrm{~km}$ of overlying nappe. The normal fault is not reactivated and all crustal shortening is accommodated by basement shearing. The basement-cover interface is sheared.

is sheared (Fig. 10f). In the hangingwall of the modelled inherited normal fault, the top-to-the-E shearing of the basement-cover interface could be linked to Wdipping S1 cleavage observed in the Bourg d'Oisans and Mizoen basins at the base of the cover (Fig. 3, green cleavage). This W-dipping S1 cleavage can be only deciphered close to the basement-cover interface and is interpreted as due to an early top-to-the-E shearing of the basement-cover interface (Fig. 3). Moreover, small E-verging back-thrust/shear zones are observed below the basement-cover interface in numerical models (Fig. 5b, i) like in the Mizoën basin (Fig. 3, below the Alps decollement).
Interestingly, in the Subalpine chains, the SaintLaurent basin is restored as the cover of the western Belledonne massif (Deville \& Chauviere, 2000; Bellahsen et al. 2014; Fig. 2). This basin marked the approximate western limit of the internal units overthrusting above the external zone and therefore was buried below a very thin nappe (Bellanger et al. 2015). The inherited normal fault was reactivated as a thrust fault associated with a shortcut fault in the basement (Figs 2, 10b). The kinematics of the inverted basin is similar to models where partial (Fig. 10e) or complete (Fig. 10d) normal fault reactivation occurred. Thus, the Saint-Laurent basin inversion could show an 
intermediate state between a complete reactivation of the fault and a basin inversion without fault reactivation.

\section{Conclusions}

In this contribution, we investigated the inversion style of inherited extensional basins using 2D thermomechanical modelling. We show that the inversion style of well-oriented inherited extensional basins is controlled by internal fault friction at shallow depth and by burial of the basin and crustal thermicity at depth. Increasing temperature and tectonic burial favour distributed deformation underneath the basin and inhibit normal fault reactivation independently of its effective friction. The absence of inherited fault reactivation and the occurrence of basement folding trigger the vertical extrusion of the basin. Then, the cover is extruded out of the basin leading to the shearing of the basement-cover interface, which develops even when no pre-existing weak layer at the base of the cover is ascribed.

These results are consistent with the collisional kinematics in the external Western Alps. In the Subalpine chains (e.g. Vercors-Chartreuse), there was (almost) no tectonic burial and the inherited normal faults were reactivated. Further east, in the Grandes Rousses and Oisans ECMs, burial of the inherited extensional basin reached about $10 \mathrm{~km}$, the temperature peak exceeded $300{ }^{\circ} \mathrm{C}$ and the inherited normal faults were not reactivated. In those basins, the basement was deformed by distributed shear zones (responsible for basement antiforms) while the cover was dysharmonically folded. These results show that the role of temperature, especially through tectonic burial, is critical in passive margin or rift inversion in mountain belts.

Acknowledgements. GALE is software hosted by the Computational Infrastructure for Geodynamics (CIG) and developed by CIG, Monash University and the Victorian Partnership for Advanced Computing (VPAC). M. Bellanger, O. Lacombe, L. Jolivet, F. Mouthereau and A. Verlaguet are thanked for fruitful discussions. D. Frizon de Lamotte and J. Armitage as reviewers and F. Nilfouroushan as editor are thanked for their constructive reviews that improved the manuscript.

\section{References}

BArbier, R., BArféty, J. C., Bocquet, A., Bordet, P., Le Fort, P., Meloux, J., Mouterde, R., PÊCHER, A. \& Petiteville, M. 1973. Carte géologique de la France (1/50.000), feuille de La Grave (798). Orléans: Bureau de Recherches Géologiques et Minières.

Barféty, J. C., Bordet, P., Carme, F., Debelmas, J., Meloux, M., Montuuvent, G., Mouterde, R. \& SARROT-REYNAULD, J. 1972. Carte géologique de la France (1/50.000), feuille de Vizille (797). Orléans: Bureau de Recherches Géologiques et Minières.

BArféty, J. C., Gidon, M., Lemoine, M. \& Mouterde, R. 1979. Tectonique synsédimentaire liasique dans les massifs cristallins de la zone externe des Alpes occidentales françaises: la faille du col d'Ornon. Comptes Rendus de
l'Académie des Sciences, Série 2, Mécanique, Physique, Chimie, Sciences de l'univers, Sciences de la Terre $\mathbf{2 8 9}$, 1207-10.

Bauville, A. \& Schmalholz, S. M. 2015. Transition from thin- to thick-skinned tectonics and consequences for nappe formation: Numerical simulations and applications to the Helvetic nappe system, Switzerland. Tectonophysics 665, 101-17.

Beaumont, C., Mufioz, J. A., Hamilton, J. \& Fullsack, P. 2000. Factors controlling the Alpine evolution of the central Pyrenees inferred from a comparison of observations and geodynamical models. Journal of Geophysical Research 105, 8121-45.

Bellahsen, N., Jolivet, L., Lacombe, O., Bellanger, M., Boutoux, A., Garcia, S., Mouthereau, F. Le Pourhiet, L. \& GumiauX, C. 2012. Mechanisms of margin inversion in the external Western Alps: implications for crustal rheology. Tectonophysics 560-561, 6283.

Bellahsen, N., Mouthereau, F., Boutoux, A., Bellanger, M., LACOMBe, O., Jolivet, L. \& Rolland, Y. 2014. Collision kinematics in the western external Alps. Tectonics 33, 1-34.

Bellanger, M., Augier, R., Bellahsen, N., Jolivet, L., Monié, P., BAudin, T. \& BeysSAC, O. 2015. Shortening of the European Dauphinois margin (Oisans Massif, Western Alps): new insights from RSCM maximum temperature estimates and ${ }^{40} \mathrm{Ar} /{ }^{39} \mathrm{Ar}$ in situ dating. Journal of Geodynamics 83, 37-64.

Bellanger, M., Bellahsen, N., Jolivet, L., Baudin, T., AUGIER, R. \& BOUTOUX, A. 2014. Basement shear zones development and shortening kinematics in the Ecrins Massif, Western Alps. Tectonics 33, 84-111.

Bonini, M., SANI, F. \& ANTONIElli, B. 2012. Basin inversion and contractional reactivation of inherited normal faults: a review based on previous and new experimental models. Tectonics 522-523, 55-88.

Bonnet, C., Malavieille, J., Mosar, J., Bonini, M., SANI, F. \& ANTONIELLI, B. 2007. Basin inversion and contractional reactivation of inherited normal faults: a review based on previous and new experimental models. Tectonophysics 26, TC6016, doi: 10.1016/j.tecto.2011.11.014.

BoutouX, A., Bellahsen, N., Lacombe, O., Verlaguet, A. \& MOUTHEREAU, F. 2014a. Inversion of pre-orogenic extensional basins in the external Western Alps: structure, microstructures and restoration. Journal of Structural Geology 60, 13-29.

Boutoux, A., Verlaguet, A., Bellahsen, N., Lacombe, O., Villemant, B., CARon, B., Martin, E., AssayaG, N. \& CARTIGNY, P. 2014b. Fluid systems above basement shear zones during inversion of pre-orogenic sedimentary basins (External Crystalline Massifs, Western Alps). Lithos 206-207, 435-53.

Buiter, S. J. H. \& Pfiffner, O. A. 2003. Numerical models of the inversion of half-graben basins. Tectonics 22, 1057, doi: 10.1029/2002TC001417.

Buiter, S. J. H., Pfiffner, O. A. \& BeAumont, C. 2009. Inversion of extensional sedimentary basins: a numerical evaluation of the localisation of shortening. Earth and Planetary Science Letters 288, 492-504.

BuRKHARD, M. 1988. L'Hélvetique de la bordure occidentale du massif de l'Aar (évolution tectonique et métamorphique) Eclogae Geologicae Helvetiae 81, 63-114.

BurkHARD, M. \& SOMmaruga, A. 1998. Evolution of the western Swiss Molasse basin: structural relations with the Alps and the Jura belt. In Cenozoic Foreland Basins of Western Europe (eds A. Mascle, C. Puigdefäbregas, 
H. P. Luterbacher \& M. Fernàndez), pp. 279-98. Geological Society of London, Special Publication no. 134.

Burov, B. \& Diament, M. 1995. The effective elastic thickness $\left(T_{\mathrm{e}}\right)$ of continental lithosphere: what does it really mean? Journal of Geophysical Research: Solid Earth 100 (B3), 3905-27.

BUTLER, R. W. H. 1989. The influence of pre-existing basin structure on thrust system evolution in the Western Alps. In Inversion Tectonics (eds M. A. Cooper \& G. D. Williams), pp. 105-22. Geological Society of London, Special Publication no. 44.

Butler, R. W. H., Tavarnelli, E. \& Grasso, M. 2006. Structural inheritance in mountain belts: an AlpineApennine perspective. Journal of Structural Geology 28, 1893-908.

Cenki-ToK, B., DARling, J. R., Rolland, Y., Dhuime, B. \& STOREY, C. D. 2013. Direct dating of mid-crustal shear zones with synkinematic allanite: new in situ $\mathrm{U}-\mathrm{Th}-\mathrm{Pb}$ geochronological approaches applied to the Mont Blanc massif. Terra Nova 26 (1), 29-37.

Colletta, B., Le Quellec, P., Letouzey, J. \& Moretti, I. 1988. Longitudinal evolution of the Suez rift structure (Egypt). Tectonophysics 153, 221-33.

Crouzet, C., Ménard, G. \& Rochette, P. 2001. Cooling history of the Dauphinoise Zone (Western Alps, France) deduced from the thermopaleomagnetic record: geodynamic implications. Tectonophysics 340, 79-93.

Deville, É. \& Chauvière, A. 2000. Thrust tectonics at the front of the western Alps: constraints provided by the processing of seismic reflection data along the Chambéry transect. Comptes Rendus l'Académie des Science, Série 2, Sciences de la Terre et des Planètes 331, 72532.

Deville, É., Mascle, A., Lamiraux, C. \& Le Bras, A. 1994. Tectonic styles, reevaluation of plays in southeastern France. Oil Gas Journal 31, 53-8.

Dumont, T., Champagnac, J.-D., Crouzet, C. \& Rochat, P. 2008. Multistage shortening in the Dauphiné zone (French Alps): the record of Alpine collision and implications for pre-Alpine restoration. Swiss Journal of Geosciences 101, 89-110.

Dumont, T., Schwartz, S. \& Guillot, S. 2012. Structural and sedimentary records of the Oligocene revolution in the Western Alpine arc. Journal of Geodynamics 56-57, $18-38$.

Escher, A., Masson, H. \& Steck, A. 1993. Nappe geometry in the western Swiss Alps. Journal of Structural Geology 15, 501-9.

GiLlcrist, R., COWARD, M. \& MUGNIER, J.-L. 1987. Structural inversion and its controls: examples from the Alpine foreland and the French Alps. Geodinamica Acta 1, 5-34.

GleAsON, C. \& Tullis, J. 1995. A flow law for dislocation creep of quartz aggregates determined with the molten salt cell. Tectonophysics 44 (1-4), 1-23.

Graciansky, P. DE, DARDEAU, G., LEMOINE, M. \& TRICART, P. 1989. The inverted margin of the French Alps and foreland basin inversion. Inversion Tectonics (eds M. A. Cooper \& G. D. Williams), pp. 87-104. Geological Society of London, Special Publication no. 44.

Gratier, J.-P. \& Vialon, P. 1980. Deformation pattern in a heterogeneous material: folded and cleaved sedimentary cover immediately overlying a crystalline basement (Oisans, French Alps). Tectonophysics 65, 151-79.

JACKSON, J. 1980. Reactivation of basement fault and crustal shortening in orogenic belts. Nature 283, 343-6.

Jullien, M. \& GofFé, B. 1993. Occurences de cookéïte et de pyrophyllite dans les schistes du Dauphinois (Isère,
France): conséquences sur la répartition du métamorphisme dans les zones externes alpines. Schweirsche Mineralogische und Petrographische Mitteilungen 73, 35763.

Kirschner, D. L., Masson, H. \& Sharp, Z. D. 1999. Fluid migration through thrust faults in the Helvetic nappes (Western Swiss Alps). Contribution to Mineralogy and Petrology 136, 169-83.

Lacombe, O. \& Bellahsen, N. 2016. Thick-skinned tectonics and basement-involved fold-thrust belts: insights from selected Cenozoic orogens. Geological Magazine, published online 20 April 2016. doi: 10.1017/S0016756816000078.

LACOMBE, O. \& MouthereaU, F. 2002. Basement-involved shortening and deep detachment tectonics in forelands of orogens: insights from recent collision belts (Taiwan, Western Alps, Pyrenees). Tectonics 21, 12-1-12-22. doi: 10.1029/2001TC901018.

Lemiale, V., Mühlhaus, H.-B., MoResi, L. \& Stafford, J. 2008. Shear banding analysis of plastic models formulated for incompressible viscous flows. Physics of the Earth and Planetary Interiors 171, 177-86.

Lemoine, M., Bas, T., Arnaud-Vanneau, A., Arnaud, H., DuMONT, T., GIDON, M., BOURBON, M., GraCiANSKY, P. De, Rudkiewicz, J., Megard-Galli, J. \& TRICART, P. 1986. The continental margin of the Mesozoic Tethys in the Western Alps. Marine and Petroleum Geology 3, 179-99.

Lemoine, M., Dardeau, G., DelPeCh, P. Y., Dumont, T., DE GRACIANSKY, P. C., GRAHAM, R., JOLIVET, L., ROBERTS, D. \& TRICART, P. 1989. Extension synrift et failles transformantes jurassiques dans les Alpes occidentales. Comptes Rendus de l'Académie des Sciences. Série 2, Mécanique, Physique, Chimie, Sciences de l'univers, Sciences de la Terre 309 (17), 1711-6.

Le Pourhiet, L., Huet, B., May, D., Labrousse, L. \& JOLIVET, L. 2012. Kinematic interpretation of the 3D shapes of metamorphic core complexes. Geochemistry, Geophysics, Geosystems 13 (9), Q09002. doi: 10.1029/2012GC004271.

MARShAK, S., KARLSTROM, K. \& TimmONS, J. 2000. Inversion of Proterozoic extensional faults: an explanation for the pattern of Laramide and Ancestral Rockies intracratonic deformation, United States. Geology 28, 735-8.

Moresi, L., Dufour, F. \& Mühlhaus, H.-B. 2003. A Lagrangian integration point finite element method for large deformation modeling of viscoelastic geomaterials. Journal of Computational Physics 184, 476-97.

MouthereaU, F., WATTS, A. B. \& BUROV, E. 2013. Structure of orogenic belts controlled by lithosphere age. Nature Geoscience 6, 785-9.

Nilfouroushan, F., Pysklywec, R., Cruden, A. \& Koyi, H. 2013. Thermal mechanical modeling of salt-based mountain belts with pre-existing basement faults: application to the Zagros Fold and Thrust Belt, Southwest Iran. Tectonics 32 (5), 1212-26.

Rolland, Y., CoX, S. F., Boullier, A.-M., Pennacchioni, G. \& MANCKTELOW, N. S. 2003. Rare earth and trace element mobility in mid-crustal shear zones: insights from the Mont Blanc Massif (Western Alps). Earth and Planetary Science Letters 214, 203-19.

Rolland, Y., Rossi, M., Cox, S. F., Corsini, M., Mancktelow, N. S., Pennacchioni, G., Fornari, M. \& Boullier, A. 2008. ${ }^{40} \mathrm{Ar} /{ }^{39} \mathrm{Ar}$ dating of synkinematic white mica: insights from fluid-rock reaction in low-grade shear zones (Mont Blanc Massif) and constraints on timing of deformation in the NW external Alps. In The Internal Structure of Fault Zones: 
Implications for Mechanical and Fluid-Flow Properties (eds C. A. J. Wibberley, W. Kurz, J. Imber, R. E. Holdsworth \& C. Collettini), pp. 293-315. Geological Society of London, Special Publication no. 299

Roure, F. \& COllettA, B. 1996. Cenozoic inversion structures in the foreland of the Pyrenees and Alps. Mémoires du Muséum national d'histoire naturelle 170, 173-209.

Sanchez, G., Rolland, Y., Schneider, J., Corsini, M., Oliot, E., Goncalves, P., Verati, C., LardeauX, J.M. \& MARQUER, D. 2011. Dating low-temperature deformation by ${ }^{40} \mathrm{Ar} /{ }^{39} \mathrm{Ar}$ on white mica, insights from the
Argentera-Mercantour Massif (SW Alps). Lithos 125, 521-36.

Simon-Labric, T., Rolland, Y., Dumont, T., Heymes, T., Authemayou, C., Corsini, M. \& Fornari, M. 2009. ${ }^{40} \mathrm{Ar} /{ }^{39} \mathrm{Ar}$ dating of Penninic Front tectonic displacement (W Alps) during the Lower Oligocene (31-34 Ma). Terra Nova 21, 127-36.

TRICART, P. \& LEMOINE, M. 1986. From faulted blocks to megamullions and megaboudins: Tethyan heritage in the structure of the Western Alps. Tectonics 5, 95-118. 